Article

\title{
Synthesis and physico-chemical characterization of novel dicyclopropyl-thiazole compounds as non-toxic and promising antifungals
}

\author{
Anna Biernasiuk ${ }^{*}$, Anna Banasiewicz², Maciej Masłyk³, Aleksandra Martyna ${ }^{3}$, Monika Janeczko ${ }^{3}$, \\ Angelika Baranowska-Łączkowska ${ }^{4}$, Anna Malm ${ }^{1}$, Krzysztof Z. Łączkowski ${ }^{2}$
}

1 Department of Pharmaceutical Microbiology, Faculty of Pharmacy, Medical University of Lublin, Chodźki 1, 20-093 Lublin, Poland; anna.biernasiuk@umlub.pl (A.B.); anna.malm@umlub.pl (A.M.)

2 Department of Chemical Technology and Pharmaceuticals, Faculty of Pharmacy, Collegium Medicum, Nicolaus Copernicus University, Jurasza 2, 85-089 Bydgoszcz, Poland; banasiewicz.anna@o2.pl (A.Ba); krzysztof.laczkowski@cm.umk.pl (K.Z.L.)

3 Department of Molecular Biology, Faculty of Science and Health, The John Paul II Catholic University of Lublin, Konstantynów 1i, 20-708 Lublin, Poland; maciekm@kul.pl (M.M.); aleksandra.martyna@kul.pl; (A.Ma.); mjanec@kul.pl (M.J.)

4 Institute of Physics, Kazimierz Wielki University, Powstańców Wielkopolskich 2, 85-090, Bydgoszcz, Poland; angelika.baranowska@ukw.edu.pl (A.B.L.)

* Correspondence: anna.biernasiuk@umlub.pl ; Tel.: +48 814487100 (A.B.)

\begin{abstract}
There is a need to search for new antifungals, especially for the treatment of the invasive Candida infections, caused mainly by C. albicans. These infections are steadily increasing at an alarming rate, mostly among immunocompromised patients. The newly synthesized compounds (3a-3k) were characterized by physico-chemical parameters and investigated for antimicrobial activity using the microdilution broth method to estimate minimal inhibitory concentration (MIC). Additionally, their antibiofilm activity and mode of action together with the effect on the membrane permeability in C. albicans were investigated. Biofilm biomass and its metabolic activity were quantitatively measured using crystal violet (CV) staining and tetrazolium salt (XTT) reduction assay. The cytotoxic effect on normal human lung fibroblasts and hemolytic effect were also evaluated. The results showed differential activity of the compounds against yeasts (MIC = $0.24-500 \mu \mathrm{g} / \mathrm{mL}$ ) and bacteria $($ MIC $=125-1000 \mu \mathrm{g} / \mathrm{mL}$ ). Most compounds possessed strong antifungal activity (MIC $=0.24-7.81 \mu \mathrm{g} / \mathrm{mL}$ ). The compounds $3 \mathrm{~b}, 3 \mathrm{c}$, and $3 \mathrm{e}$, showed no inhibitory (at 1/2 MIC) and eradication (at $8 \times$ MIC) effect on C. albicans biofilm. Only slight decrease in the biofilm metabolic activity was observed for compound $3 \mathrm{~b}$. Moreover, the studied compounds increased the permeability of the membrane/cell wall of $C$. albicans and their mode of action may be related to action within the fungal cell wall structure and/or within the cell membrane. It is worth noting that the compounds had no cytotoxicity effect on pulmonary fibroblasts and erythrocytes at concentrations showing anticandidal activity. The present studies in vitro confirm that these derivatives appear to be a very promising group of antifungals for further preclinical studies.
\end{abstract}

Keywords: antifungal activity; Candida albicans; antibiofilm effect; mode of action; cytotoxicity; hemolytic assay; HOMO-LUMO; molecular electrostatic potential

\section{Introduction}

In the last years, the prevalence of Candida infections, which ranges from superficial to deep-seated invasive candidiasis, has increased at an alarming rate, especially among immunocompromised individuals [1,2]. Given the fact that at least $50 \%$ of healthy individuals are the carriers of Candida species, these commensal microorganisms are regarded as potentially pathogenic in susceptible hosts. Infections caused by Candida spp. are primarily depended on the immunological status of the host. Both local and systemic risk factors may result in weakened immune functions that mediate Candida colonisation 
on host surfaces. These fungi mostly affects neutropenic patients, individuals with haematological malignancies, older patients, diabetics or individuals pre-exposed to azoles or echinocandins [1-5]. The most common isolated Candida species of clinical significance in fungal invasive infection is Candida albicans. It is associated with the occurrence of mortality rates as high as $35-50 \%(6,7]$. Non-albicans Candida spp. (NAC) like C. glabrata, C. krusei, C. tropicalis or C. parapsilosis are also serious nosocomial threats. Most manifestations of candidiasis are associated with biofilm formation occurring on the surfaces of host tissues and medical devices [3,8,9]. Moreover, the most important feature of Candida biofilms is its role in increasing tolerance to conventional antifungal therapy. The optimal protection of the embedded cells against noxious agents, e.g., antibiotics and the immune system, is the main reason why biofilm infections are so difficult to treat. It has been found that for the eradication of pathogens from biofilms more than 1000 times higher antibiotic concentrations were required than for the same strain living in planktonic form $[10,11]$. Currently, the list of the commercially available antifungal agents, used for the treatment of infections caused by Candida spp. is limited to three major classes: polyenes (e.g. amphotericin B or nystatin), azoles (e.g. fluconazole or posaconazole) and echinocandins (e.g. caspofungin or micafungin) [6,7]. The treatment of fungal infections is often ineffective and there is a need to search for new antifungals.

The chemistry of thiazoles is currently widely developed due to the relatively easy synthesis of a wide range of compounds, which enables studying the relationship between their structure and properties [12,13]. Due to the nonlinear optical properties (NLO) of the thiazole system, it is used in optical devices such as photovoltaic detectors or light emitting diodes [14]. However, its greatest advantage is that it exhibits a wide range of biological properties, such as antimicrobial [15-18], anticancer [19-21], anticonvulsant [22], antioxidant [23] as well as anti-SARS-CoV-2 [24]. Numerous studies, including those carried out over the years by our group, show that thiazole derivatives have high antifungal activity $[3,25]$. The cyclopropane system, due to its unique properties, such as low molecular weight, conformational rigidity, unusual bonding and planarity, is used in drug design as replacements for gem-dimethyl and alkene groups, and also phenyl ring, leading to reduced lipophilicity and increased metabolic stability of drugs [26,27]. We have recently shown that thiazole derivatives containing a cyclopropane ring exhibit high activity against both reference strains and clinical isolates of Candida spp. with minimal inhibitory concentration (MIC) ranging from 0.008 to 7.81 $\mu \mathrm{g} / \mathrm{mL}$ comparable or even higher than that of nystatin [28,29]. Additionally, the designed derivatives showed lower toxicity compared to nystatin.

The promising results prompted us to synthesize of thiazole derivatives containing two cyclopropyl groups and then to investigate their antifungal activity against Candida spp.

Better understanding of the intermolecular interactions involving drug molecules and its reactivity is possible applying modern quantum chemistry methods. A widely employed example here are approximations based on the density functional theory (DFT). In the present study, the DFT is used in to find optimal geometrical parameters of the investigated compounds as well as to evaluate the shape and the energy of their highest occupied molecular orbital (HOMO) and the lowest unoccupied molecular orbital (LUMO). These are the two main orbitals involved in chemical reactions, with the HOMO playing the role of an electron donor, and LUMO - of an electron acceptor. Within the present work, their energies are denoted as Еномо and Ецимо, respectively. The HOMO-LUMO energy gap $\Delta E$ is defined as:

$$
\Delta E=\text { Ецимо }- \text { Еномо, }
$$

and gives insight into the molecule's activity. Low values of $\Delta E$ result in higher chemical activity and lower kinetic stability of the compound, while high $\Delta E$ values - in lower chemical activity and higher kinetic stability. The knowledge on the HOMO and LUMO energy values allows to evaluate electron affinity $E A$, ionization potential $I P$, molecule's hardness $\eta$, softness $S$, and electronegativity $\chi$. 
The molecule's $E A$ informs about molecule's reductant properties, and is related to the LUMO energy:

$$
E A=- \text { Ецим } .
$$

By definition, $E A$ is the energy released upon gaining an electron by a molecule. The $I P$ is the energy needed to remove an electron from a molecule. Thus, the lower IP means an easier electron removal, that is a larger tendency of the molecule to donate electrons. Its value is related to the HOMO energy as:

$$
I P=- \text { Еномо } .
$$

Molecule's electronegativity $\chi$ instead can be defined as [30]:

$$
\chi=(I P+E A) / 2 \text {, }
$$

and represents its ability to attract electrons. Molecule's hardness $\eta$ is the inverse of molecule's softness $S$, and is defined as [30]:

$$
\eta=1 / S=(I P-E A) / 2 .
$$

The larger values of $\eta$, the larger molecule's resistance to change the number of electrons. Additionally, within the present work the molecular electrostatic potential (MEP) surfaces are calculated for the investigated systems. They allow to indicate molecular sites susceptible to nucleophilic or electrophilic attacks.

In the present work the novel dicyclopropyl-thiazole compounds were designed, synthesized and characterized by physico-chemical parameters as well as they were investigated in the aspect of the antimicrobial activity. Additionally, we conducted a screening study of their antibiofilm activity together with their mode of action and the effect on the membrane permeability in C. albicans. The cytotoxic effect on normal human lung fibroblasts and erythrocytes we also evaluated.

\section{Materials and Methods}

\subsection{Chemistry}

All experiments were carried out under air atmosphere unless stated otherwise. Reagents were generally the best quality commercial-grade products and were used without further purification. ${ }^{1} \mathrm{H}$ NMR $(700 \mathrm{MHz})$ and ${ }^{13} \mathrm{C}$ NMR $(176 \mathrm{MHz})$ spectra were recorded on a Bruker Avance III multinuclear instrument. ESI-(+)-HRMS was performed by the Laboratory for Analysis of Organic Compounds and Polymers of the Centre for Molecular and Macromolecular Studies of the Polish Academy of Science in Łódź. Melting points were determined in open glass capillaries and are uncorrected. Analytical TLC was performed using Macherey-Nagel Polygram Sil G/UV254 $0.2 \mathrm{~mm}$ plates. Dicyclopropyl ketone, thiosemicarbazide and appropriate bromoketones were commercial materials (Sigma-Aldrich Chemicals, St. Louis, Mo., USA).

\subsubsection{Synthesis and Structural Characterization}

2-(Dicyclopropylmethylene)hydrazinecarbothioamide (1)

Thiosemicarbazide $(1.82 \mathrm{~g}, 20.0 \mathrm{mmol})$ was added to a stirred solution of dicyclopropyl ketone $(\mathbf{1})(2.20 \mathrm{~g}, 20.0 \mathrm{mmol})$ in absolute ethyl alcohol $(30 \mathrm{ml})$ and then $(1.0 \mathrm{ml})$ of acetic acid was added. The reaction mixture was stirred under reflux for 20 hours under nitrogen atmosphere. Next, the reaction mixture was added to water $(50 \mathrm{ml})$ and neutralized with $\mathrm{NaHCO}_{3}$ solution. The product was extracted with dichloromethane $(2 \times 100 \mathrm{ml})$, the solvent was evaporated in vacuo to afford the desired product to yield

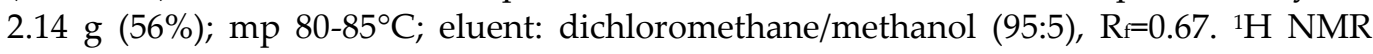
(DMSO-d6, 700MHz); $\delta(\mathrm{ppm}): 0.54-0.61\left(\mathrm{~m}, 2 \mathrm{H}, \mathrm{CH}_{2}\right) ; 0.73-0.78\left(\mathrm{~m}, 2 \mathrm{H}, \mathrm{CH}_{2}\right) ; 0.84-0.92$ $\left(\mathrm{m}, 4 \mathrm{H}, 2 \mathrm{CH}_{2}\right) ; 1.13-1.18(\mathrm{~m}, 1 \mathrm{H}, \mathrm{CH}) ; 2.10-2.16(\mathrm{~m}, 1 \mathrm{H}, \mathrm{CH}) ; 7.36$ (bs, $\left.1 \mathrm{H}, \mathrm{NH}_{2}\right) ; 8.00$ (bs, $\left.1 \mathrm{H}, \mathrm{NH}_{2}\right) ; 10.00$ (bs, $\left.1 \mathrm{H}, \mathrm{NH}\right) .{ }^{13} \mathrm{C}$ NMR (DMSO-d, $\left.175 \mathrm{MHz}\right) ; \delta(\mathrm{ppm}): 6.33\left(\mathrm{CH}_{2}\right) ; 7.42$ $\left(\mathrm{CH}_{2}\right) ; 10.38\left(\mathrm{CH}_{2}\right) ; 11.52\left(\mathrm{CH}_{2}\right) ; 11.75(\mathrm{CH}) ; 20.52(\mathrm{CH}) ; 157.83(\mathrm{C}=\mathrm{N}) ; 178.62(\mathrm{C}=\mathrm{S})$. 
Typical procedure Carbothioamide $2(0.183 \mathrm{~g}, 1.0 \mathrm{mmol})$ was added to a stirred solution of 2-bromo-1-(4-fluorophenyl)ethanone $(0.217 \mathrm{~g}, 1.0 \mathrm{mmol})$ in absolute ethyl alcohol (25 $\mathrm{ml}$ ). The reaction mixture was stirred under room temperature for 20 hours, and separated precipitate was collected by filtration to afford the desired product to yield 0.16 $\mathrm{g}$, 53\%, (dichloromethane, $\mathrm{R}_{\mathrm{f}}=0.49$ ); $\mathrm{mp} 135-138^{\circ} \mathrm{C} .{ }^{1} \mathrm{H}$ NMR (DMSO-d6, $700 \mathrm{MHz}$ ); $\delta$ (ppm): 0.62-0.70 (m, 4H, 2CH 2$) ; 0.89-0.98\left(\mathrm{~m}, 4 \mathrm{H}, 2 \mathrm{CH}_{2}\right) ; 1.17-1.26(\mathrm{~m}, 1 \mathrm{H}, \mathrm{CH}) ; 2.06-2.15$ (m, 1H, CH); 7.19 (s, 1H, CH); 7.20-7.26 (m, 2H, 2CH); 7.83-7.89 (m, 2H, 2CH); 10.98 (bs, $1 \mathrm{H}, \mathrm{NH}) .{ }^{13} \mathrm{C}$ NMR (DMSO-d6, $\left.175 \mathrm{MHz}\right) ; \delta(\mathrm{ppm}): 6.47\left(2 \mathrm{CH}_{2}\right) ; 7.13\left(2 \mathrm{CH}_{2}\right) ; 11.24(\mathrm{CH}) ;$ $12.18(\mathrm{CH}) ; 103.78$ (CHthiazole $) ; 115.94\left(2 \mathrm{CH}_{\text {Ar }}\right) ; 128.18\left(2 \mathrm{CH}_{\text {Ar }}\right) ; 130.67(\mathrm{C}) ; 147.44(\mathrm{C}) ; 158.34$ $(\mathrm{C}=\mathrm{N}) ; 162.24$ (d, C-F, J=243 Hz); 170.69 (C-NH). ESI-HRMS (m/z) calculated for $\mathrm{C}_{16} \mathrm{H}_{17} \mathrm{FN}_{3} \mathrm{~S}: 302.1127[\mathrm{M}+\mathrm{H}]^{+}$. Found: $302.11127[\mathrm{M}+\mathrm{H}]^{+}$.

4-(4-Chlorophenyl)-2-(2-(dicyclopropylmethylene)hydrazinyl)thiazole (3b).

Yield: $0.10 \mathrm{~g}, 32 \%$, (dichloromethane/methanol (95:5), $\left.\mathrm{R}_{\mathrm{f}}=0.92\right) ; \mathrm{mp} 146-147^{\circ} \mathrm{C} .{ }^{1} \mathrm{H}$ NMR (DMSO-d6, $700 \mathrm{MHz}$ ); $\delta$ (ppm): 0.63-0.71 (m, 4H, 2CH $)$; 0.91-0.99 (m, 4H, 2CH $)$; 1.25-1.19 $(\mathrm{m}, 1 \mathrm{H}, \mathrm{CH}) ; 2.06-2.12(\mathrm{~m}, 1 \mathrm{H}, \mathrm{CH}) ; 7.30(\mathrm{~s}, 1 \mathrm{H}, \mathrm{CH}) ; 7.47(\mathrm{~d}, 2 \mathrm{H}, 2 \mathrm{CH}, \mathrm{J}=8.6 \mathrm{~Hz}) ; 7.81(\mathrm{~d}$, $2 \mathrm{H}, 2 \mathrm{CH}, \mathrm{J}=8.5 \mathrm{~Hz}$ ); 11.17 (bs, 1H, NH). ${ }^{13} \mathrm{C}$ NMR (DMSO-d6, $\left.175 \mathrm{MHz}\right) ; \delta(\mathrm{ppm}): 6.26$ $\left(2 \mathrm{CH}_{2}\right) ; 7.09\left(2 \mathrm{CH}_{2}\right) ; 11.19(\mathrm{CH}) ; 11.95(\mathrm{CH}) ; 104.56\left(\mathrm{CH}_{\text {thiazole }}\right) ; 127.70\left(2 \mathrm{CH}_{\mathrm{Ar}}\right) ; 129.00$ (2CHAr); 132.32 (C); $134.34(\mathrm{C}) ; 149.06(\mathrm{C}) ; 156.44(\mathrm{C}=\mathrm{N}) ; 170.93(\mathrm{C}-\mathrm{NH})$. ESI-HRMS (m/z) calculated for $\mathrm{C}_{16} \mathrm{H}_{17} \mathrm{ClN}_{3} \mathrm{~S}: 318.0832[\mathrm{M}+\mathrm{H}]^{+}$. Found: $318.0831[\mathrm{M}+\mathrm{H}]^{+}$.

4-(4-Bromophenyl)-2-(2-(dicyclopropylmethylene)hydrazinyl)thiazole (3c)

Yield: $0.16 \mathrm{~g}, 44 \%$, (dichloromethane/methanol (95:5), $\left.\mathrm{R}_{\mathrm{f}}=0.45\right) ; \mathrm{mp} 139-140^{\circ} \mathrm{C}$. ${ }^{1} \mathrm{H}$ NMR (DMSO-d6, $700 \mathrm{MHz}) ; \delta$ (ppm): 0.62-0.69 (m, 4H, 2CH2); 0.89-0.98 (m, 4H, 2CH2); 0.18-1.23 $(\mathrm{m}, 1 \mathrm{H}, \mathrm{CH}) ; 2.06-2.12(\mathrm{~m}, 1 \mathrm{H}, \mathrm{CH}) ; 7.30(\mathrm{~s}, 1 \mathrm{H}, \mathrm{CH}) ; 7.59(\mathrm{~d}, 2 \mathrm{H}, 2 \mathrm{CH}, \mathrm{J}=8.4 \mathrm{~Hz}) ; 7.76(\mathrm{~d}$, $2 \mathrm{H}, 2 \mathrm{CH}, \mathrm{J}=8.4 \mathrm{~Hz}$ ); 11.13 (bs, 1H, NH). ${ }^{13} \mathrm{C}$ NMR (DMSO-d6, $\left.175 \mathrm{MHz}\right) ; \delta(\mathrm{ppm}): 6.34$ $\left(2 \mathrm{CH}_{2}\right) ; 7.16\left(2 \mathrm{CH}_{2}\right) ; 11.21(\mathrm{CH}) ; 12.04(\mathrm{CH}) ; 104.73\left(\mathrm{CH}_{\text {thiazole }}\right) ; 121.08(\mathrm{C}) ; 128.07\left(2 \mathrm{CH}_{\mathrm{Ar}}\right)$; $131.97\left(2 \mathrm{CH}_{\mathrm{Ar}}\right) ; 148.57(\mathrm{C}) ; 157.18(\mathrm{C}=\mathrm{N}) ; 170.87(\mathrm{C}-\mathrm{NH})$. ESI-HRMS (m/z) calculated for $\mathrm{C}_{16} \mathrm{H}_{17} \mathrm{BrN}_{3} \mathrm{~S}: 362.0327[\mathrm{M}+\mathrm{H}]^{+}$. Found: $362.0328[\mathrm{M}+\mathrm{H}]^{+}$.

4-(2-(2-(Dicyclopropylmethylene)hydrazinyl)thiazol-4-yl)benzonitrile (3d)

Yield: $0.18 \mathrm{~g}, 58 \%$, (dichloromethane/methanol (95:5), $\left.\mathrm{R}_{\mathrm{f}}=0.85\right) ; \mathrm{mp} 138-140^{\circ} \mathrm{C} .{ }^{1} \mathrm{H}$ NMR (DMSO-d6, $700 \mathrm{MHz}) ; \delta$ (ppm): 0.61-0.68 (m, 4H, 2CH $)$; 0.88-0.97 (m, 4H, 2CH$) ; 1.17-1.23$ $(\mathrm{m}, 1 \mathrm{H}, \mathrm{CH}) ; 2.07-2.13(\mathrm{~m}, 1 \mathrm{H}, \mathrm{CH}) ; 7.52(\mathrm{~s}, 1 \mathrm{H}, \mathrm{CH}) ; 7.84(\mathrm{~d}, 2 \mathrm{H}, 2 \mathrm{CH}, \mathrm{J}=8.5 \mathrm{~Hz}) ; 8.00$ (d, $2 \mathrm{H}, 2 \mathrm{CH}, \mathrm{J}=6.9 \mathrm{~Hz}) ; 11.08$ (bs, 1H, NH). ${ }^{13} \mathrm{C}$ NMR (DMSO-d6, $\left.175 \mathrm{MHz}\right) ; \delta(\mathrm{ppm}): 6.30$ $\left(2 \mathrm{CH}_{2}\right) ; 7.14\left(2 \mathrm{CH}_{2}\right) ; 11.18(\mathrm{CH}) ; 12.01(\mathrm{CH}) ; 107.64$ (CHthiazole); 109.99 (C); 119.41 (C); 126.60 (2CHAr); 133.07 (2CHAr); $139.27(\mathrm{C}) ; 148.69(\mathrm{C}) ; 156.83(\mathrm{C}=\mathrm{N}) ; 171.11(\mathrm{C}-\mathrm{NH})$. ESI-HRMS (m/z) calculated for $\mathrm{C}_{17} \mathrm{H}_{17} \mathrm{~N}_{4} \mathrm{~S}: 309.1174[\mathrm{M}+\mathrm{H}]^{+}$. Found: $309.1181[\mathrm{M}+\mathrm{H}]^{+}$.

2-(2-(Dicyclopropylmethylene)hydrazinyl)-4-p-tolylthiazole (3e)

Yield: $0.16 \mathrm{~g}, 53 \%$, (dichloromethane, $\mathrm{R}_{\mathrm{f}}=0.32$ ); $\mathrm{mp} 128-131^{\circ} \mathrm{C} .{ }^{1} \mathrm{H}$ NMR (DMSO-d6, 700 $\mathrm{MHz}) ; \delta$ (ppm): 0.63-0.72 (m, 4H, 2CH $)$; 0.90-1.00 (m, 4H, 2CH $) ; 0.18-1.27$ (m, 1H, CH); 2.06-2.15 (m, 1H, CH); $2.32\left(\mathrm{~s}, 3 \mathrm{H}, \mathrm{CH}_{3}\right) ; 7.14(\mathrm{~s}, 1 \mathrm{H}, \mathrm{CH}) ; 7.21$ (d, 2H, 2CH, J = 7.9 Hz); 7.71 (d, 2H, 2CH, J = 8.1 Hz); 10.96 (bs, 1H, NH). ${ }^{13} \mathrm{C}$ NMR (DMSO-d6, $\left.175 \mathrm{MHz}\right) ; \delta(\mathrm{ppm})$ : $6.57\left(2 \mathrm{CH}_{2}\right) ; 7.45\left(2 \mathrm{CH}_{2}\right) ; 11.32(\mathrm{CH}) ; 12.34(\mathrm{CH}) ; 21.27\left(\mathrm{CH}_{3}\right) ; 103.20\left(\mathrm{CH}_{\text {thiazole }}\right) ; 126.12$ (2CHAr); 129.72 (2CHAr); 130.61 (C); 138.02 (C); 147.28 (C); 159.50 (C=N); 170.46 (C-NH). ESI-HRMS (m/z) calculated for $\mathrm{C}_{17} \mathrm{H}_{20} \mathrm{~N}_{3} \mathrm{~S}: 298.1378[\mathrm{M}+\mathrm{H}]^{+}$. Found: $298.1380[\mathrm{M}+\mathrm{H}]^{+}$.

4-(4-Azidophenyl)-2-(2-(dicyclopropylmethylene)hydrazinyl)thiazole (3f)

Yield: $0.12 \mathrm{~g}$, 65\%, (dichloromethane, $\mathrm{R}_{\mathrm{f}}=0.34$ ); mp 144-147 ${ }^{\circ} \mathrm{C} .{ }^{1} \mathrm{H}$ NMR (DMSO-d, 700 $\mathrm{MHz}) ; \delta$ (ppm): 0.61-0.68 (m, 4H, 2CH$) ; 0.88-0.97$ (m, 4H, 2CH $)$; 1.17-1.23 (m, 1H, CH); 2.06-2.13 (m, 1H, CH); $7.14(\mathrm{~d}, 2 \mathrm{H}, 2 \mathrm{CH}, \mathrm{J}=6.5 \mathrm{~Hz}) ; 7.20(\mathrm{~s}, 1 \mathrm{H}, \mathrm{CH}) ; 7.86(\mathrm{~d}, 2 \mathrm{H}, 2 \mathrm{CH}, \mathrm{J}=$ $8.5 \mathrm{~Hz}) ; 11.01$ (bs, 1H, NH). ${ }^{13} \mathrm{C}$ NMR (DMSO-d6, $\left.175 \mathrm{MHz}\right) ; \delta(\mathrm{ppm}): 6.37\left(2 \mathrm{CH}_{2}\right) ; 7.21$ $\left(2 \mathrm{CH}_{2}\right) ; 11.23(\mathrm{CH}) ; 12.06(\mathrm{CH}) ; 103.78$ ( $\left.\mathrm{CH}_{\text {thiazole }}\right) ; 119.81\left(2 \mathrm{CH}_{\mathrm{Ar}}\right) ; 127.68$ (2CHAr); 129.43 
(C); 138.96 (C); 148.50 (C); 157.48 (C=N); 170.75 (C-NH). ESI-HRMS (m/z) calculated for $\mathrm{C}_{16} \mathrm{H}_{17} \mathrm{~N} 6 \mathrm{~S}: 325.1235[\mathrm{M}+\mathrm{H}]^{+}$. Found: $325.1238[\mathrm{M}+\mathrm{H}]^{+}$.

2-(2-(Dicyclopropylmethylene)hydrazinyl)-4-(4-(trifluoromethyl)phenyl)thiazole (3g)

Yield: $0.21 \mathrm{~g}, 61 \%$, (dichloromethane, $\mathrm{R}_{\mathrm{f}}=0.58$ ); $\mathrm{mp} 157-159^{\circ} \mathrm{C}$. ${ }^{1} \mathrm{H}$ NMR (DMSO-d6, 700 $\mathrm{MHz}) ; \delta$ (ppm): 0.61-0.67 (m, 4H, 2CH $) ; 0.88-0.97$ (m, 4H, 2CH $)$; 1.17-1.23 (m, 1H, CH); 2.07-2.13 (m, 1H, CH); $7.45(\mathrm{~s}, 1 \mathrm{H}, \mathrm{CH}) ; 7.74(\mathrm{~d}, 2 \mathrm{H}, 2 \mathrm{CH}, \mathrm{J}=8.3 \mathrm{~Hz}) ; 8.04(\mathrm{~d}, 2 \mathrm{H}, 2 \mathrm{CH}, \mathrm{J}=$ $8.1 \mathrm{~Hz}) ; 11.05$ (bs, 1H, NH). ${ }^{13} \mathrm{C}$ NMR (DMSO-d6, $\left.175 \mathrm{MHz}\right) ; \delta(\mathrm{ppm}): 6.29\left(2 \mathrm{CH}_{2}\right) ; 7.13$ $\left(2 \mathrm{CH}_{2}\right) ; 11.18(\mathrm{CH}) ; 12.00(\mathrm{CH}) ; 106.57$ (CHthiazole); $124.05(\mathrm{C}) ; 125.98\left(2 \mathrm{CH}_{\mathrm{Ar}}\right) ; 126.53$ $\left(2 \mathrm{CH}_{\text {Ar }}\right) ; 127.99$ (q, C, JC-F $\left.=31.7 \mathrm{~Hz}\right) ; 138.81(\mathrm{C}) ; 148.72(\mathrm{C}) ; 156.77(\mathrm{C}=\mathrm{N}) ; 171.08(\mathrm{C}-\mathrm{NH})$. ESI-HRMS (m/z) calculated for $\mathrm{C}_{17} \mathrm{H}_{17} \mathrm{~F}_{3} \mathrm{~N}_{3} \mathrm{~S}$ : $352.1095[\mathrm{M}+\mathrm{H}]^{+}$. Found: $352.1096[\mathrm{M}+\mathrm{H}]^{+}$.

2-(2-(Dicyclopropylmethylene)hydrazinyl)-4-(4-nitrophenyl)thiazole (3h)

Yield: 0.32 g, 99\%, (dichloromethane, $\mathrm{R}_{\mathrm{f}}=0.33$ ); $\mathrm{mp} 141-143^{\circ} \mathrm{C} .{ }^{1} \mathrm{H}$ NMR (DMSO-d6, 700 $\mathrm{MHz}) ; \delta$ (ppm): 0.63-0.70 (m, 4H, 2CH$) ; 0.89-1.00\left(\mathrm{~m}, 4 \mathrm{H}, 2 \mathrm{CH}_{2}\right) ; 1.17-1.26(\mathrm{~m}, 1 \mathrm{H}, \mathrm{CH})$; 2.07-2.17 (m, 1H, CH); $7.61(\mathrm{~s}, 1 \mathrm{H}, \mathrm{CH}) ; 8.10(\mathrm{~d}, 2 \mathrm{H}, 2 \mathrm{CH}, \mathrm{J}=9.1 \mathrm{~Hz}) ; 8.27(\mathrm{~d}, 2 \mathrm{H}, 2 \mathrm{CH}, \mathrm{J}=$ $9.1 \mathrm{~Hz}) ; 11.08$ (bs, 1H, NH). ${ }^{13} \mathrm{C}$ NMR (DMSO-d6, $\left.175 \mathrm{MHz}\right) ; \delta(\mathrm{ppm}): 6.30\left(2 \mathrm{CH}_{2}\right) ; 7.13$ $\left(2 \mathrm{CH}_{2}\right) ; 11.17(\mathrm{CH}) ; 12.00(\mathrm{CH}) ; 108.67\left(\mathrm{CH}_{\text {thiazole }}\right) ; 124.50\left(2 \mathrm{CH}_{\mathrm{Ar}}\right) ; 126.78\left(2 \mathrm{CH}_{\mathrm{Ar}}\right) ; 141.30$ (C); $146.62(\mathrm{C}) ; 148.55(\mathrm{C}) ; 156.73(\mathrm{C}=\mathrm{N}) ; 171.23$ (C-NH). ESI-HRMS (m/z) calculated for $\mathrm{C}_{16} \mathrm{H}_{17} \mathrm{~N}_{4} \mathrm{O}_{2} \mathrm{~S}: 329.1072[\mathrm{M}+\mathrm{H}]^{+}$. Found: $329.1071[\mathrm{M}+\mathrm{H}]^{+}$.

3-Chloro-N-(4-(2-(2-(dicyclopropylmethylene)hydrazinyl)thiazol-4-yl)phenyl)propanami de (3i)

Yield: 0.18 g, 46\%, (dichloromethane/methanol (95:5), $\left.\mathrm{R}_{\mathrm{f}}=0.52\right) ; \mathrm{mp} 210-213^{\circ} \mathrm{C} .{ }^{1} \mathrm{H}$ NMR (DMSO-d6, $700 \mathrm{MHz}$ ); $\delta$ (ppm): 0.62-0.70 (m, 4H, 2CH 2 ); 0.90-0.98 (m, 4H, 2CH $) ; 1.19-1.25$ $(\mathrm{m}, 1 \mathrm{H}, \mathrm{CH}) ; 2.06-2.12(\mathrm{~m}, 1 \mathrm{H}, \mathrm{CH}) ; 2.83(\mathrm{t}, 2 \mathrm{H}, 2 \mathrm{CH}, \mathrm{J}=6.1 \mathrm{~Hz}) ; 3.88(\mathrm{t}, 2 \mathrm{H}, 2 \mathrm{CH}, \mathrm{J}=6.2$ $\mathrm{Hz}) ; 7.11(\mathrm{~s}, 1 \mathrm{H}, \mathrm{CH}) ; 7.64(\mathrm{~d}, 2 \mathrm{H}, 2 \mathrm{CH}, \mathrm{J}=8.5 \mathrm{~Hz}) ; 7.75(\mathrm{~d}, 2 \mathrm{H}, 2 \mathrm{CH}, \mathrm{J}=8.6 \mathrm{~Hz}) ; 10.25$ (bs, $1 \mathrm{H}, \mathrm{NH}) ; 11.03$ (bs, 1H, NH). ${ }^{13} \mathrm{C}$ NMR (DMSO-d6, $\left.175 \mathrm{MHz}\right) ; \delta(\mathrm{ppm}): 6.40\left(2 \mathrm{CH}_{2}\right) ; 7.32$ $\left(2 \mathrm{CH}_{2}\right) ; 11.35(\mathrm{CH}) ; 12.16(\mathrm{CH}) ; 41.21\left(\mathrm{CH}_{2}\right) ; 102.63$ (CHthiazole); 119.67 (2CHAr); 126.49 (2CHAr); $128.81(\mathrm{C}) ; 139.25(\mathrm{C}) ; 147.59(\mathrm{C}) ; 158.38(\mathrm{C}=\mathrm{N}) ; 168.47(\mathrm{C}=\mathrm{O}) ; 170.51(\mathrm{C}-\mathrm{NH})$. ESI-HRMS (m/z) calculated for $\mathrm{C}_{19} \mathrm{H}_{22} \mathrm{ClN}_{4} \mathrm{OS}: 389.1203[\mathrm{M}+\mathrm{H}]+$. Found: $389.1202[\mathrm{M}+\mathrm{H}]^{+}$.

2-Chloro-N-(4-(2-(2-(dicyclopropylmethylene)hydrazinyl)thiazol-4-yl)phenyl)acetamide (3j)

Yield: $0.14 \mathrm{~g}, 37 \%$, (dichloromethane/methanol (95:5), $\mathrm{R}_{\mathrm{f}}=0.83$ ); $\mathrm{mp}>300^{\circ} \mathrm{C} .{ }^{1} \mathrm{H}$ NMR (DMSO-d6, $700 \mathrm{MHz}$ ); $\delta$ (ppm): 0.61-0.68 (m, 4H, 2CH 2 ); 0.88-0.96 (m, 4H, 2CH $)$; 1.18-1.22 $(\mathrm{m}, 1 \mathrm{H}, \mathrm{CH}) ; 2.07-2.13(\mathrm{~m}, 1 \mathrm{H}, \mathrm{CH}) ; 4.26\left(\mathrm{~s}, 2 \mathrm{H}, \mathrm{CH}_{2}\right) ; 7.12(\mathrm{~s}, 1 \mathrm{H}, \mathrm{CH}) ; 7.62(\mathrm{~d}, 2 \mathrm{H}, 2 \mathrm{CH}, \mathrm{J}$ $=8.8 \mathrm{~Hz}) ; 7.78(\mathrm{~d}, 2 \mathrm{H}, 2 \mathrm{CH}, \mathrm{J}=7.8 \mathrm{~Hz}) ; 10.43(\mathrm{bs}, 1 \mathrm{H}, \mathrm{NH}) ; 11.03(\mathrm{bs}, 1 \mathrm{H}, \mathrm{NH}) .{ }^{13} \mathrm{C}$ NMR (DMSO-d6, $175 \mathrm{MHz}) ; \delta(\mathrm{ppm}): 6.41\left(2 \mathrm{CH}_{2}\right) ; 7.28\left(2 \mathrm{CH}_{2}\right) ; 11.32(\mathrm{CH}) ; 12.15(\mathrm{CH}) ; 44.02$ $\left(\mathrm{CH}_{2}\right) ; 102.91$ (CHthiazole); 119.93 (2CHAr); 126.55 (2CHAr); $129.54(\mathrm{C}) ; 138.65(\mathrm{C}) ; 147.89(\mathrm{C})$; $158.15(\mathrm{C}=\mathrm{N}) ; 165.15(\mathrm{C}=\mathrm{O}) ; 170.57 \quad(\mathrm{C}-\mathrm{NH})$. ESI-HRMS $(\mathrm{m} / \mathrm{z})$ calculated for $\mathrm{C}_{18} \mathrm{H}_{20} \mathrm{ClN} 4 \mathrm{OS}: 375.1046[\mathrm{M}+\mathrm{H}]^{+}$. Found: $375.1047[\mathrm{M}+\mathrm{H}]^{+}$.

4-(3,4-Dichlorophenyl)-2-(2-(dicyclopropylmethylene)hydrazinyl)thiazole (3k)

Yield: $0.27 \mathrm{~g}, 77 \%$, (dichloromethane, $\mathrm{R}_{\mathrm{f}}=0.68$ ); $\mathrm{mp} 152-154^{\circ} \mathrm{C} .{ }^{1} \mathrm{H}$ NMR (DMSO-d6, 700 $\mathrm{MHz}) ; \delta$ (ppm): 0.63-0.70 (m, 4H, 2CH2); 0.89-0.98 (m, 4H, 2CH2); 1.17-1.26 (m, 1H, CH); 2.07-2.16 (m, 1H, CH); $7.43(\mathrm{~s}, 1 \mathrm{H}, \mathrm{CH}) ; 7.64(\mathrm{~d}, 2 \mathrm{H}, 2 \mathrm{CH}, \mathrm{J}=8.3 \mathrm{~Hz}) ; 7.81(\mathrm{dd}, 1 \mathrm{H}, \mathrm{CH}$, $\mathrm{J}_{1}=1.8 \mathrm{~Hz}, \mathrm{~J}_{2}=8.6 \mathrm{~Hz}$ ); 11.01 (bs, $\left.1 \mathrm{H}, \mathrm{NH}\right) .{ }^{13} \mathrm{C}$ NMR (DMSO-d6, $\left.175 \mathrm{MHz}\right) ; \delta(\mathrm{ppm}): 6.28$ $\left(2 \mathrm{CH}_{2}\right) ; 7.12\left(2 \mathrm{CH}_{2}\right) ; 11.19(\mathrm{CH}) ; 11.99(\mathrm{CH}) ; 106.02\left(\mathrm{CH}_{\text {thiazole }}\right) ; 126.01(\mathrm{C}) ; 127.68(\mathrm{C})$; 130.07 (C); 131.26 (C); 131.88 (C); 135.73 (C); 147.76 (C); 156.75 (C=N); 171.00 (C-NH). ESI-HRMS (m/z) calculated for $\mathrm{C}_{16} \mathrm{H}_{16} \mathrm{Cl}_{2} \mathrm{~N}_{3} \mathrm{~S}: 352.0442[\mathrm{M}+\mathrm{H}]^{+}$. Found: $352.0444[\mathrm{M}+\mathrm{H}]^{+}$. 
The reference strains of microorganisms from American Type Culture Collection (ATCC) were included. The representative Gram-positive bacteria were: Staphylococcus aureus ATCC 6538, Staphylococcus aureus ATCC 25923, Staphylococcus epidermidis ATCC 12228, Micrococcus luteus ATCC 10240, Bacillus subtilis ATCC 6633 and Bacillus cereus ATCC 10876, while those of Gram-negative bacteria: Escherichia coli ATCC 25922, Proteus mirabilis ATCC 12453, Klebsiella pneumoniae ATCC 13883, Salmonella Typhimurium ATCC 14028, Pseudomonas aeruginosa ATCC 9027 and Bordetella bronchiseptica ATCC 4617. Moreover, the fungi belonging to yeasts (Candida albicans ATCC 2091, Candida albicans ATCC 10231, Candida parapsilosis ATCC 22019, Candida glabrata ATCC 90030 and Candida krusei ATCC 14243) were used.

\subsection{Cell Culture}

The CCD-11Lu (CCL-202) cell line (normal human lung fibroblasts) was obtained from ATCC. Cells were cultured in DMEM (Dulbecco's Modified Eagle Medium, high glucose $)+$ GlutaMAX supplemented with penicillin $(50 \mu \mathrm{g} / \mathrm{mL})$, streptomycin $(50 \mathrm{U} / \mathrm{mL})$ and $10 \%$ heat-inactivated FBS. Cells were maintained in a humidified atmosphere at $37^{\circ} \mathrm{C}$ and $5 \% \mathrm{CO}_{2}$ and passaged twice before performing an experiment.

\subsection{In Vitro Antimicrobial Activity Assay}

The examined compounds $\mathbf{3} \mathbf{a}-\mathbf{3} \mathbf{k}$ were screened in vitro for antibacterial and antifungal activities using the broth microdilution method according to European Committee on Antimicrobial Susceptibility Testing (EUCAST) [31] and Clinical and Laboratory Standards Institute (CLSI) guidelines [32]. All the used microbial cultures were first subcultured on nutrient agar (for bacteria) or Sabouraud agar (for fungi). The surface of Mueller-Hinton agar and RPMI (Roswell Park Memorial Institute) 1640 with MOPS (3-(N-Morpholino)propanesulfonic acid) (Sigma-Aldrich, USA) were inoculated with the suspensions of bacterial or fungal species, respectively. Microbial suspensions were prepared in sterile saline $(0.85 \% \mathrm{NaCl})$ with an optical density of $0.5 \mathrm{McF}$ arland standard scale. Samples containing examined compounds were dissolved in dimethyl sulfoxide (DMSO). Furthermore, bacterial and fungal suspensions were put onto Petri dishes with solid media containing $2 \mathrm{mg} / \mathrm{mL}$ of the tested compounds followed incubation under appropriate conditions. The inhibition of microbial growth was judged by comparison with a control culture prepared without any sample tested. Ciprofloxacin or nystatin (Sigma-Aldrich, USA) were used as a reference antibacterial or antifungal compounds, respectively [31,32].

Subsequently MIC (Minimal Inhibitory Concentration) of the compounds was examined by the microdilution broth method, using their two-fold dilutions in Mueller-Hinton broth (for bacteria) and RPMI 1640 broth with MOPS (for fungi) prepared in 96-well polystyrene plates. Final concentrations of the compounds ranged from 1000 to $0.0038 \mu \mathrm{g} / \mathrm{mL}$. Microbial suspensions were prepared in sterile saline with an optical density of 0.5 McFarland standard. Next bacterial or fungal suspension was added per each well containing broth and various concentrations of the examined compounds. After incubation, the MIC was assessed spectrophotometric as the lowest concentration of the samples showing complete bacterial or fungal growth inhibition. Appropriate DMSO, growth and sterile controls were carried out. The medium with no tested substances was used as control [31,32].

The MBC (Minimal Bactericidal Concentration) or MFC (Minimal Fungicidal Concentration) are defined as the lowest concentration of the compounds that is required to kill a particular bacterial or fungal species. MBC or MFC was determined by removing the culture using for MIC determinations from each well and spotting onto appropriate agar medium. The plates were incubated. The lowest compounds concentrations with no visible growth observed were assessed as a bactericidal or fungicidal concentration. All the experiments were repeated three times in independent and representative data are presented [31,32]. 


\subsection{Antibiofilm Activity Assay}

Candida albicans ATCC 10231 was grown as biofilms using polystyrene flat-bottomed microtiter plates. The cell suspension was prepared in RPMI 1640 medium at a cell density of $2 \times 10^{6}$ cells $/ \mathrm{mL}$ and dispensed into the wells of two microtiter plates $(100 \mu \mathrm{L}$ per well). The effect of the selected compounds $3 \mathbf{b}, 3 \mathbf{c}$ and $3 \mathbf{e}$ on the biofilm-forming ability was tested in the presence of $100 \mu \mathrm{L}$ of different concentrations $(1 / 8 \times \mathrm{MIC}, 1 / 4 \mathrm{x}$ MIC, and $1 / 2 \times$ MIC). $100 \mu \mathrm{L}$ of RPMI 1640 medium containing $1 \%$ DMSO without compounds was control. The plates were incubated for $48 \mathrm{~h}$ at $37^{\circ} \mathrm{C}$. At the end of incubation medium was aspirated from the wells and planktonic-phase were removed by washing the biofilms three times with PBS (Phosphate-Buffered Saline, pH 7.4). Biofilms were dried at $60^{\circ} \mathrm{C}$ for $2 \mathrm{~h}$. Biofilm formation (based on its biomass) was determined by crystal violet (CV) assay described by Feoktistova M. et al. [35], and its metabolic activity by colorimetric XTT [2,3-bis(2-methoxy-4-nitro-5-sulfophenyl)-2H-tetrazolium-5carboxanilide sodium salt] reduction assay as previously reported [36,37]. The studies were performed using a spectrophotometer (the absorbance was measured at $570 \mathrm{~nm}$ and $490 \mathrm{~nm}$ in CV staining and XTT reduction assay, respectively).

For the preformed biofilms the cell suspension was prepared in RPMI 1640 at a cell density of $1 \times 10^{6}$ cells $/ \mathrm{mL} .100 \mu \mathrm{L}$ of cell suspension was dispensed into the wells and incubated at $37{ }^{\circ} \mathrm{C}$ for 2 days. After incubation, the non-adherent cells were gently removed and the wells were washed three times with PBS and filled with $100 \mu \mathrm{L}$ two-fold dilutions of compounds in RPMI 1640 corresponding to MIC, $2 \times$ MIC, and $8 x$ MIC. For control, $100 \mu \mathrm{L}$ of RPMI 1640 medium containing final 1\% DMSO was added into the selected wells of biofilms. Further, microtiter plates were incubated at $37^{\circ} \mathrm{C}$ for 2 days. Subsequent to the appropriate incubation medium was aspirated from the wells and nonadherent cells were removed by washing the biofilms as described previously. The CV staining of dry biofilms and colorimetric XTT reduction assay were performed according to method cited above. Each experiment was repeated three times as independent assays.

\subsection{Membrane Permeability Assay}

Alteration of membrane permeability of C. albicans ATCC 10231 was evaluated using a crystal violet $(\mathrm{CV})$ assay proposed by Lee $\mathrm{HS}$ et al. [38]. C. albicans cells at the exponential phase were harvested by centrifugation at $4500 \times \mathrm{g}$ at $4{ }^{\circ} \mathrm{C}$ for $5 \mathrm{~min}$. The cells were washed twice and resuspended in $0.85 \% \mathrm{NaCl}$. The tested compounds $\mathbf{3 b}, \mathbf{3} \mathbf{c}$ and $\mathbf{3 e}$ corresponding to the concentrations of MIC, $2 \times$ MIC or $8 \times$ MIC were added to the suspension and incubated at $37^{\circ} \mathrm{C}, 200 \mathrm{rpm}$ for $8 \mathrm{~h}$. Solvent (DMSO) controls were included for each compound. Cells were harvested and washed in $0.85 \% \mathrm{NaCl}$, and the cell density was adjusted in each experimental group to equate to $1 \times 10^{8}$ cells $/ \mathrm{mL}$. Next, the cells were resuspended in $0.85 \% \mathrm{NaCl}$ solution containing $10 \mu \mathrm{g} / \mathrm{mL}$ of $\mathrm{CV}$. The cell suspensions were incubated at $37^{\circ} \mathrm{C}, 200 \mathrm{rpm}$ for $10 \mathrm{~min}$. The cells were precipitated by centrifugation at $12000 \mathrm{xg}$ at $4{ }^{\circ} \mathrm{C}$ for $15 \mathrm{~min}$, and the amount of $\mathrm{CV}$ remaining in the supernatant was measured at $590 \mathrm{~nm}$ using a spectrophotometer. The OD values of the initial crystal violet solution used in the assay were regarded as $100 \%$. The percentage of crystal violet uptake of all cells was calculated as follows: uptake of crystal violet $(\%)=$ (A590 of the sample)/(A590 of crystal violet solution) x 100.

\subsection{Sorbitol Assay}

To investigate the effect of the newly synthesized compounds $3 \mathbf{b}, \mathbf{3} \mathbf{c}$ and $\mathbf{3 e}$ on the cell wall of C. albicans ATCC 10231, the sorbitol assay was used. The sorbitol (Sigma-Aldrich, USA) was added to the culture medium in a final concentration of 0.8 $M$. The MICs of the newly thiazole derivatives towards yeast, using Sabouraud Dextrose Broth (SDB) medium (BioMaxima S.A., Poland) in the presence and absence of sorbitol (as control) were determined in different lines of the same microplate. The microdilution technique was performed in triplicate according to the guidelines other authors [33,34,39-42]. After filling each well of the microplates with $100 \mu \mathrm{L}$ of SDB and $100 \mu \mathrm{L}$ of 
SDB supplemented with sorbitol, serial dilutions of studied compounds and nystatin (as control) ranging from 0.03 to $1000 \mu \mathrm{g} / \mathrm{mL}$ were carried out. In the next stage, $10 \mu \mathrm{L}$ of $C$. albicans suspension $\left(10^{6} \mathrm{CFU} / \mathrm{mL}\right)$ was added to each well. The appropriate controls: yeast growth and sterility were also performed. MICs were read after 2 and 7 days incubation at $37^{\circ} \mathrm{C}$ as the lowest concentrations of tested compounds capable of visually inhibiting the candidal growth.

\subsection{Ergosterol Assay}

To assess if these compounds $3 \mathbf{b}, \mathbf{3} \mathbf{c}$ and $\mathbf{3 e}$ bind to the fungal membrane sterols of C. albicans ATCC 10231, test with ergosterol was performed according to the procedure previously reported [39-42]. The stock solution of exogenous ergosterol (Sigma-Aldrich, USA) at final concentration $10 \mathrm{mg} / \mathrm{mL}$ in the liquid RPMI-1640 medium with DMSO (no more than $10 \%$ of final volume) with addition 1\% Tween 80 (Pol-Aura, Poland) was prepared. The MICs of the newly derivatives towards yeast were determined by the broth microdilution method $[33,34]$ with and without exogenous ergosterol, added to the RPMI-1640 medium in different lines of the same microplate. The ergosterol was transferred to the wells in a final concentration of $400 \mu \mathrm{g} / \mathrm{mL}$. After filling each well of the microplates with $100 \mu \mathrm{L}$ of medium with and without ergosterol, serial dilutions of newly synthesized compounds and nystatin (as control) ranging from 0.03 to 1000 $\mu \mathrm{g} / \mathrm{mL}$ were carried out. Then, $10 \mu \mathrm{L}$ of yeast suspension $\left(10^{6} \mathrm{CFU} / \mathrm{mL}\right)$ was added to each well. After 24-hour incubation at $35^{\circ} \mathrm{C}$ MIC was determined as the lowest concentration of tested compounds inhibiting the visible growth of $C$. albicans. Yeast growth and sterility were also controlled.

\subsection{Cytotoxicity Assay}

For cytotoxicity assay normal human lung fibroblasts were seeded in 96-well microplates at a density of $2,5 \times 10^{4}$ cells $/ \mathrm{mL}$ in $100 \mu \mathrm{L}$ DMEM + GlutaMAX supplemented with $10 \%$ heat-inactivated FBS (Fetal Bovine Serum) in three sets for different periods of tested compound $3 \mathbf{b}, 3 \mathbf{c}$, and $3 \mathbf{e}$ exposure. After $24 \mathrm{~h}$ of cell attachment, plates were washed with $100 \mu \mathrm{L} /$ well with phosphate buffered saline (PBS) and the cells were treated with five concentrations $(0.25,0.5,1,10$ and $25 \mu \mathrm{g} / \mathrm{mL}$ final concentration) of each compound prepared in fresh FBS-free medium for 24,48 and $72 \mathrm{~h}$. Each concentration was tested in triplicate. All sets included wells containing $0.01 \%$ DMSO as a negative control. Cytotoxicity of compounds was assessed using the MTT-based colorimetric assay described below. MTT is 3-(4,5-dimethylthiazol-2-yl)-2,5diphenyl tetrazolium bromide and exists as a yellow tetrazolium salt. This test indicates the number of viable cells and the level of metabolic activity in a sample [43]. Following 24,48 and $72 \mathrm{~h}$ of compound exposure, control medium or test exposures medium were removed, the cells were rinsed with PBS and $100 \mu \mathrm{L}$ of fresh medium (without FBS or antibiotics) was added to each well. $10 \mu \mathrm{L}$ of MTT $(5 \mathrm{mg} / \mathrm{mL})$ prepared in PBS was added to each well and the plates were incubated for $3 \mathrm{~h}$ at $37{ }^{\circ} \mathrm{C}$ in a $5 \% \mathrm{CO}_{2}$ humidified incubator. After incubation period the medium was discarded, the cells were washed with $100 \mu \mathrm{L}$ of PBS and $100 \mu \mathrm{l}$ of DMSO was added to each well to extract the dye. The plate was shaken for $10 \mathrm{~min}$ and the absorbance was measured at $570 \mathrm{~nm}$. Viability was calculated as the ratio of the mean of OD obtained for each condition to the control condition.

\subsection{Hemolytic Activity Assay}

The blood was collected in sterile tubes containing citrate dextrose solution as an anticoagulant. To separate erythrocytes from plasma, the samples were centrifuged at $500 \times \mathrm{g}$ for $10 \mathrm{~min}$ at $4^{\circ} \mathrm{C}$, and the supernatant was removed. Next, the erythrocytes were resuspended in PBS buffer $(10 \mathrm{mM}$ phosphate, $\mathrm{pH} 7.5 ; 150 \mathrm{mM} \mathrm{NaCl})$ and centrifuged at $500 \times \mathrm{g}$ for $10 \mathrm{~min}$ at $4^{\circ} \mathrm{C}$. The washing procedure was repeated until a transparent supernatant was obtained. After washing, the erythrocytes were resuspended in PBS buffer at a final concentration of $2 \%$. Simultaneously, the compounds were prepared at 
the MIC, $2 \times$ MIC, $5 \times$ MIC, $10 \times$ MIC concentrations in a final volume of $50 \mu \mathrm{L}$ DMSO. The prepared compounds were mixed with $450 \mu \mathrm{L}$ of the $2 \%$ erythrocyte suspension and incubated for $1 \mathrm{~h}$ at $37^{\circ} \mathrm{C}$. Next, the samples were centrifuged at $5000 \times \mathrm{g}$ for $10 \mathrm{~min}$, and absorbance was measured at a wave length of $415 \mathrm{~nm}[44,45]$.

\subsection{Quantum Chemical Calculation}

Quantum chemical investigation was performed for the three most active molecules, that is compounds $\mathbf{3} \mathbf{b}, \mathbf{3} \mathbf{c}$ and $\mathbf{3 e}$, using the Gaussian 09 package [46]. Optimization of geometrical parameters of the investigated systems was carried out at the DFT approximation, employing the B3LYP exchange-correlation functional and the $6-311 \mathrm{G}^{* *}$ basis set. The resulting structures were confirmed to be real minima on potential energy surface through calculation of the corresponding vibrational frequencies at the same level of approximation. Next, the HOMO and LUMO orbitals as well as the MEP surfaces were obtained based on the B3LYP/6-311G ${ }^{* *}$ calculations employing the Gaussian 09 package [46], and visualized with GaussView 5 [47]. The most positive electronic potential is presented in the MEP surface plots with blue colour, and the most negative one with red colour.

\section{Results}

\subsection{Chemical Synthesis and Chemoinformatics Data}

The desired (dicyclopropylmethylene)hydrazinyl)thiazoles (3a-3k) were readily prepared by a two-step reaction as shown in Scheme 1. The first step was the reaction of the appropriate dicyclopropyl ketone and thiosemicarbazide in anhydrous ethyl alcohol in the presence of acetic acid as catalyst. The 2-(dicyclopropylmethylidene) hydrazinecarbothioamide (1) was obtained in good yield (56\%). Then hydrazinecarbothioamide $\mathbf{1}$ was reacted with the appropriate bromoketones in ethyl

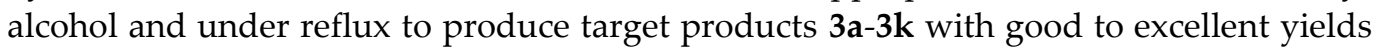
(32-99\%). All compounds were purified by silica gel column chromatography and characterized by spectroscopic methods such as ${ }^{1} \mathrm{H},{ }^{13} \mathrm{C}$ NMR, and ESI-HRMS. In the ${ }^{1} \mathrm{H}$ NMR spectrum of hydrazinecarbothioamide 1, the three signals at 7.36, 8.00 and 10.00 ppm were assigned to the protons of the $\mathrm{NH}_{2}$ and $\mathrm{NH}$ groups, respectively. In the ${ }^{1} \mathrm{H}$ NMR spectra of compounds 3a-3k, thiazole-5H protons signal at about (7.11-7.61) ppm and broadened hydrazine $\mathrm{NH}$ singlet at (10.96-11.17) ppm were observed. The conversion of the substrates to the target products was also confirmed by the ${ }^{13} \mathrm{C}$ NMR spectra. The signals at (102.63-108.67) ppm correspond to the $\mathrm{CH}$ carbon atoms in the thiazole ring. Additionally, the signals from the $\mathrm{C}=\mathrm{N}$ and $\mathrm{C}-\mathrm{NH}$ groups can be observed at about 150 and $170 \mathrm{ppm}$. Moreover, their ESI-HRMS spectra showed peaks corresponding to their molecular $[\mathrm{M}+\mathrm{H}]^{+}$ions. 

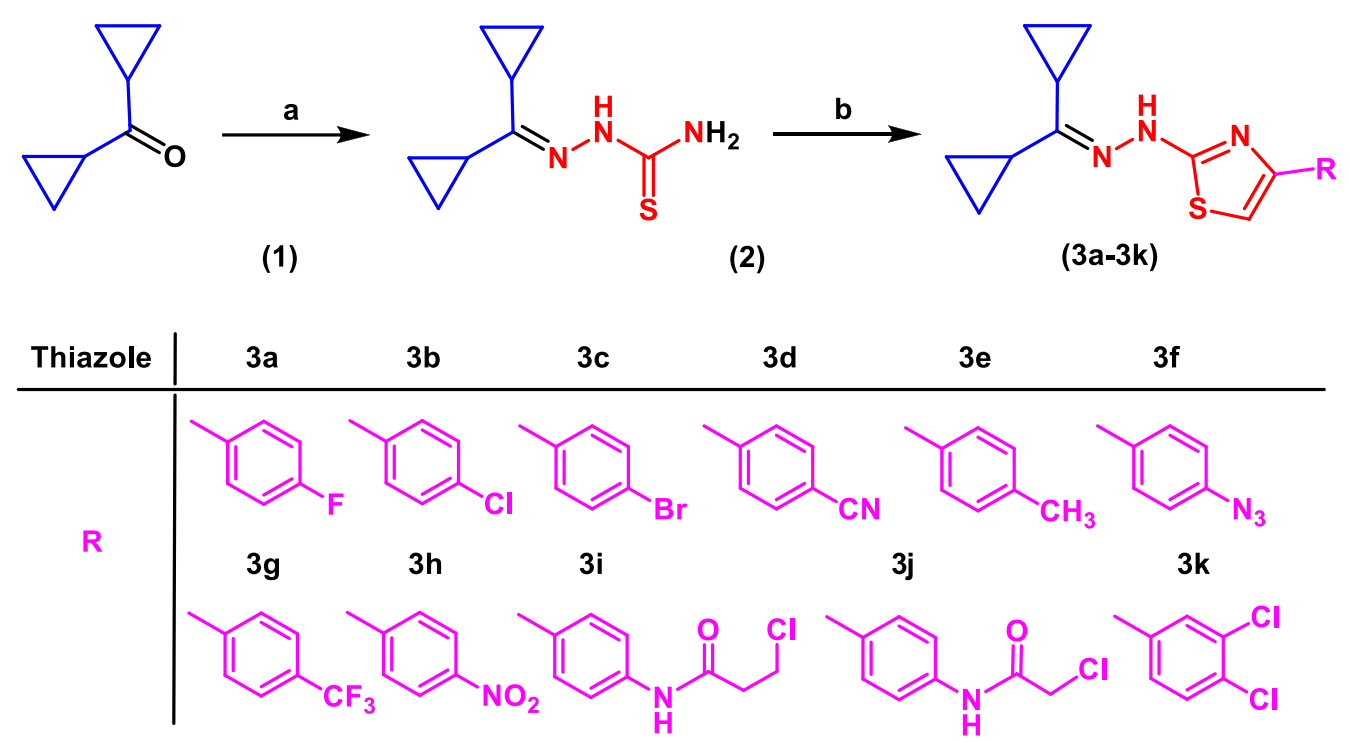

Scheme 1. Synthesis of the target thiazoles 3a-3k. (a) thiosemicarbazide, glacial acetic acid, EtOH, reflux, 24h (56\%); (b) 4-substituted-bromoacetophenones, EtOH, reflux, 24h (32-99\%).

\subsection{Quantum Chemical Calculation}

The results of quantum chemistry calculations are presented in Table 1, the shape of HOMO and LUMO orbitals in Figure 1, and the MEP surfaces in Figure 2. The HOMO orbitals have very similar shape for all three compounds, in each case covering almost the whole molecule. Analogous situation is observed for the LUMO orbitals. Values of the HOMO-LUMO energy gap are in the order of $4.2-4.3 \mathrm{eV}$ for the three investigated compounds. Energy of the HOMO and the LUMO is 0.2 and $0.3 \mathrm{eV}$, respectively, higher for the methyl derivative than for the remaining two derivatives. Consequently, the $3 \mathbf{e}$ molecule has the lowest values of ionization potential $I P$, electron affinity $E A$, and electronegativity $\chi$. Thus, among the investigated systems the electron removal is the easiest for compound $3 \mathbf{e}$. Contrary, compounds $\mathbf{3} \mathbf{c}$ and $\mathbf{3 b}$ - having the larger values of $E A$ and larger electronegativity - are the two best electron acceptors. They are also the compounds with the largest values of softness (the lowest values of hardness $\eta$ ), and thus the most active among the investigated systems.

In Figure 2, the electron-rich regions of the MEP surfaces are denoted with red colour, and those electron-deficient with blue colour. Their analysis shows that the electron-rich regions are located around nitrogen atoms in all three systems. An additional electron-rich region is located around chloro- substituent in compound $\mathbf{3 b}$ and around bromo- substituent in compound 3c. As the methyl substituent is an electron-donating group, it increases electron density in the phenyl ring, which is reflected by the MEP of 3e molecule. The electron-deficient regions are located around cyclopropyl rings.

Table 1. Predicted molecular properties for compounds $3 \mathbf{b}, 3 \mathbf{c}$ and $3 \mathbf{e}$. All results in $\mathrm{eV}$.

\begin{tabular}{ccccccccc}
\hline Compound & Еномо & Ецимо & $\boldsymbol{\Delta E}$ & $\boldsymbol{\eta}$ & $\boldsymbol{S}$ & $\boldsymbol{I P}$ & $\boldsymbol{E A}$ & $\boldsymbol{\chi}$ \\
\hline $\mathbf{3 b}$ & -5.469 & -1.208 & 4.262 & 2.131 & 0.469 & 5.469 & 1.208 & 3.339 \\
$\mathbf{3 c}$ & -5.467 & -1.216 & 4.251 & 2.125 & 0.470 & 5.467 & 1.216 & 3.342 \\
$\mathbf{3 e}$ & -5.263 & -0.932 & 4.330 & 2.165 & 0.462 & 5.263 & 0.932 & 3.097 \\
\hline
\end{tabular}



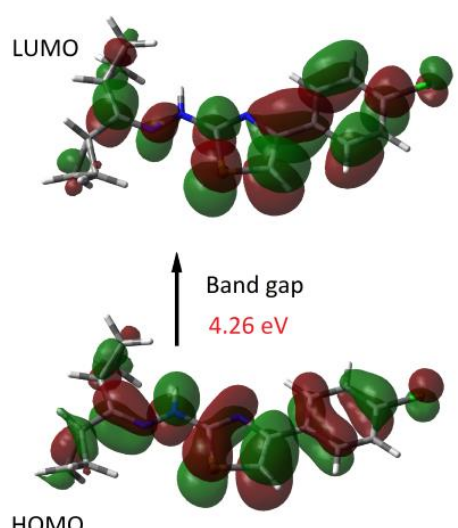

3b
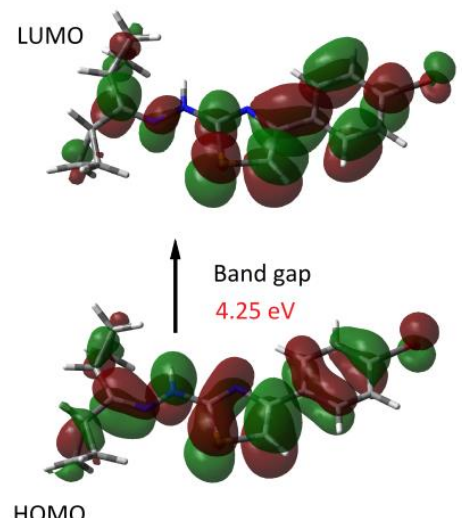

$3 c$
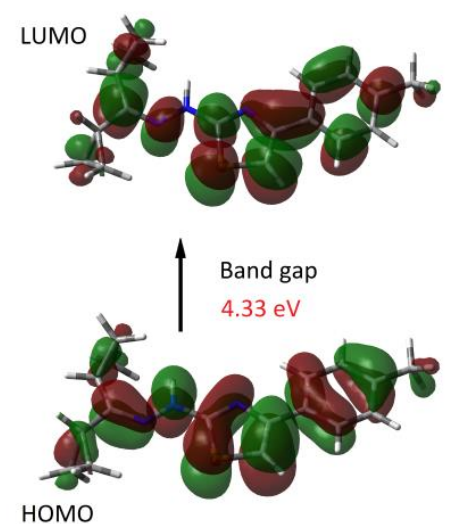

$3 e$

Figure 1. Molecular orbital distribution plots of HOMO-LUMO for compounds $3 \mathbf{b}, 3 \mathbf{c}$ and $3 \mathbf{e}$ obtained at the B3LYP/6-311G** level of approximation.

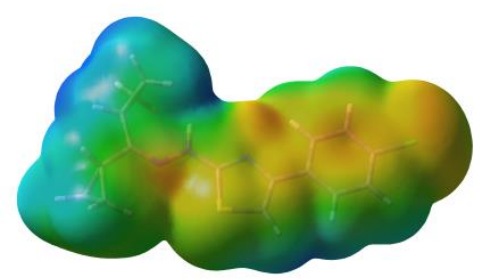

$3 \mathbf{b}$

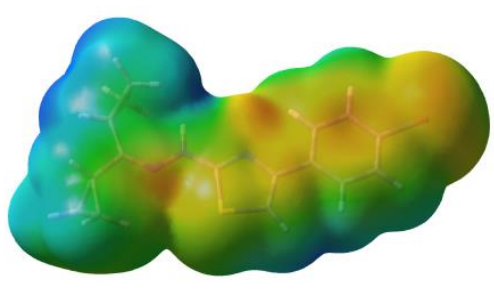

3c

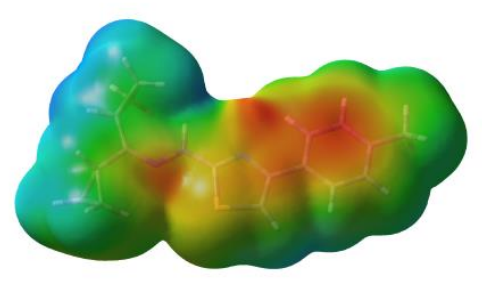

$3 e$

Figure 2. Molecular electrostatic potential (MEP) surfaces for compounds $\mathbf{3 b}, \mathbf{3 c}$ and $\mathbf{3 e}$.

\subsection{Antimicrobial Activity}

In this study, no antimicrobial activity was defined as a MIC $>1000 \mu \mathrm{g} / \mathrm{ml}$, mild activity as a MIC in the range $501-1000 \mu \mathrm{g} / \mathrm{ml}$, moderate activity with MIC from 126 to $500 \mu \mathrm{g} / \mathrm{ml}$, good activity as a MIC in the range $26-125 \mu \mathrm{g} / \mathrm{ml}$, strong activity with MIC between 10 and $25 \mu \mathrm{g} / \mathrm{ml}$ and very strong activity as a MIC $<10 \mu \mathrm{g} / \mathrm{ml}$. The MBC/MIC or MFC/MIC ratios were calculated in order to determine bactericial/fungicidal (MBC/MIC $\leq 4, \mathrm{MFC} / \mathrm{MIC} \leq 4)$ or bacteriostatic/fungistatic $(\mathrm{MBC} / \mathrm{MIC}>4$, MFC/MIC $>4$ ) effect of the tested compounds $[33,34]$.

\subsubsection{Antibacterial Activity}

On the basis of our data presented in Table 2 and 3, 3a-3k compounds had some antibacterial activity especially against the reference strains of Gram-positive bacteria. Bordetella bronchiseptica ATCC 4617 from Gram-negative bacteria was also sensitive to these substances but the remaining Gram-negative bacteria were insensitive to all studied compounds. Among these substances, $\mathbf{3 e}, \mathbf{3} \mathbf{g}$ and $\mathbf{3 k}$ had the widest spectrum of activity with MIC ranging from $31.25 \mu \mathrm{g} / \mathrm{mL}$ to $1000 \mu \mathrm{g} / \mathrm{mL}$ and MBC from $500 \mu \mathrm{g} / \mathrm{mL}$ to $>1000$ $\mu \mathrm{g} / \mathrm{mL}$ with good (3e and $\mathbf{3 k}$ ), moderate (3e, $\mathbf{3 g}$ and $\mathbf{3 k}$ ) or mild (3e and $\mathbf{3 g}$ ) effect. In turn, reference $B$. bronchiseptica strain was the most sensitive to all compounds (MIC $=31.25$ $125 \mu \mathrm{g} / \mathrm{mL}$ in the case of $\mathbf{3 a}-\mathbf{3 e}$; MIC $=250-500 \mu \mathrm{g} / \mathrm{mL}$ for $\mathbf{3 f}, \mathbf{3 h}-\mathbf{3 k}$ and MIC $=1000$ $\mu \mathrm{g} / \mathrm{mL}$ in the case of $\mathbf{3 g}$ ).

Table 2. The activity data of compounds expressed as MIC against the reference strains of bacteria. The standard antibiotic ciprofloxacin (CIP) was used as positive control.

\begin{tabular}{llllllllllllll}
\hline \multirow{3}{*}{ Species } & \multicolumn{11}{c}{ MIC $[\mu \mathrm{g} / \mathrm{mL}]$ of compounds and positive control } \\
\cline { 2 - 12 } & $3 \mathrm{a}$ & $3 \mathrm{~b}$ & $3 \mathrm{c}$ & $3 \mathrm{~d}$ & $3 \mathrm{e}$ & $3 \mathrm{f}$ & $3 \mathrm{~g}$ & $3 \mathrm{~h}$ & $3 \mathrm{i}$ & $3 \mathrm{j}$ & $3 \mathrm{k}$ & $\mathrm{CIP}$ \\
\hline
\end{tabular}




\begin{tabular}{|c|c|c|c|c|c|c|c|c|c|c|c|c|}
\hline $\begin{array}{c}\text { Staphylococcus aureus } \\
\text { ATCC } 6538\end{array}$ & - & 1000 & - & 1000 & 1000 & - & 500 & 1000 & - & 1000 & 250 & 0.24 \\
\hline $\begin{array}{c}\text { Staphylococcus aureus } \\
\text { ATCC } 25923\end{array}$ & 500 & 125 & 500 & 500 & 500 & - & 250 & 250 & 500 & 250 & 62.5 & 0.48 \\
\hline $\begin{array}{c}\text { Staphylococcus epidermidis } \\
\text { ATCC } 12228\end{array}$ & 1000 & 1000 & - & 125 & 1000 & 1000 & 250 & 125 & 250 & 500 & 250 & 0.12 \\
\hline $\begin{array}{c}\text { Micrococcus luteus } \\
\text { ATCC } 10240\end{array}$ & 250 & 125 & 125 & 500 & 125 & 1000 & 250 & 1000 & - & 250 & 250 & 0.98 \\
\hline $\begin{array}{c}\text { Bacillus subtilis } \\
\text { ATCC } 6633\end{array}$ & - & - & - & - & 1000 & - & 500 & - & - & - & 250 & 0.03 \\
\hline $\begin{array}{l}\text { Bacillus cereus } \\
\text { ATCC } 10876\end{array}$ & 1000 & 1000 & - & 1000 & 500 & - & 500 & 1000 & - & - & 250 & 0.06 \\
\hline $\begin{array}{c}\text { Bordetella bronchiseptica } \\
\text { ATCC } 4617\end{array}$ & 125 & 125 & 125 & 125 & 31.25 & 250 & 1000 & 500 & 500 & 250 & 500 & 0.98 \\
\hline
\end{tabular}

The minimal concentrations of all compounds which killed these rods were $\geq 1000$ $\mu \mathrm{g} / \mathrm{mL}$. The tested substances exhibited also similar effect against $S$. aureus ATCC 25923 (except 3f, which had no activity), Staphylococcus epidermidis ATCC 12228 (except 3c), and Micrococcus luteus ATCC 10240 (except 3i) (MIC =62.5-1000 $\mu \mathrm{g} / \mathrm{mL}$ and MBC $\geq 1000$ $\mu \mathrm{g} / \mathrm{mL}$ ). The activity of compounds $\mathbf{3 a}-\mathbf{3 k}$ towards other bacteria (S. aureus ATCC 6538 and sporulating bacilli - Bacillus subtilis ATCC 6633 and Bacillus cereus ATCC 10876) was lower - mild or moderate $(\mathrm{MIC}=250-\geq 1000 \mu \mathrm{g} / \mathrm{mL}, \mathrm{MBC}=500-\geq 1000 \mu \mathrm{g} / \mathrm{mL})$.

Table 3. The activity data of compounds expressed as $\mathrm{MBC}[\mu \mathrm{g} / \mathrm{ml}]$ and $\mathrm{MBC} / \mathrm{MIC}$ ratio against the reference strains of bacteria. The standard antibiotic - ciprofloxacin (CIP) was used control.

\begin{tabular}{|c|c|c|c|c|c|c|c|c|c|c|c|c|}
\hline \multirow[t]{2}{*}{ Species } & \multicolumn{12}{|c|}{$\mathrm{MBC}[\mu \mathrm{g} / \mathrm{ml}]$ and $\mathrm{MBC} / \mathrm{MIC}$ ratio of compounds and positive control } \\
\hline & $3 a$ & $3 b$ & $3 c$ & $3 d$ & $3 \mathbf{e}$ & $3 f$ & $3 g$ & $3 h$ & $3 \mathbf{i}$ & $3 \mathbf{j}$ & $3 \mathbf{k}$ & CIP \\
\hline Staphylococcus aureus & - & $>1000$ & - & $>1000$ & $>1000$ & - & 1000 & $>1000$ & - & $>1000$ & 500 & 0.24 \\
\hline ATCC 6538 & & $(>1)$ & & $(>1)$ & $(>1)$ & & $(2)$ & $(>1)$ & & $(>1)$ & $(2)$ & $(1)$ \\
\hline Staphylococcus aureus & $>1000$ & $>1000$ & $>1000$ & $>1000$ & $>1000$ & - & 1000 & 1000 & $>1000$ & 500 & 500 & 0.48 \\
\hline ATCC 25923 & $(>2)$ & $(>8)$ & $(>2)$ & $(>2)$ & $(>2)$ & & $(4)$ & $(4)$ & $(>2)$ & $(2)$ & $(8)$ & $(1)$ \\
\hline Staphylococcus epidermidis & $>1000$ & $>1000$ & - & 500 & $>1000$ & $>1000$ & $>1000$ & 500 & $>1000$ & 1000 & 500 & 0.12 \\
\hline ATCC 12228 & $(>1)$ & $(>1)$ & & $(4)$ & $(>1)$ & $(>1)$ & $(>4)$ & $(4)$ & $(>4)$ & $(2)$ & $(2)$ & $(1)$ \\
\hline Micrococcus luteus & 1000 & 1000 & 1000 & $>1000$ & 500 & $>1000$ & $>1000$ & $>1000$ & - & 1000 & 1000 & 1.98 \\
\hline ATCC 10240 & $(4)$ & $(8)$ & $(8)$ & $(>2)$ & (4) & $(>1)$ & $(>4)$ & $(>1)$ & & $(4)$ & $(4)$ & $(2)$ \\
\hline Bacillus subtilis & - & - & - & - & $>1000$ & - & $>1000$ & - & - & - & 1000 & 0.03 \\
\hline ATCC 6633 & & & & & $(>1)$ & & $(>2)$ & & & & $(4)$ & $(1)$ \\
\hline Bacillus cereus & $>1000$ & $>1000$ & - & $>1000$ & $>1000$ & - & $>1000$ & $>1000$ & - & - & $>1000$ & 0.12 \\
\hline ATCC 10876 & $(>1)$ & $(>1)$ & & $(>1)$ & $(>2)$ & & $(>2)$ & $(>1)$ & & & $(>4)$ & $(2)$ \\
\hline Bordetella bronchiseptica & 1000 & 1000 & $>1000$ & 1000 & 1000 & $>1000$ & $>1000$ & $>1000$ & $>1000$ & $>1000$ & $>1000$ & 0.98 \\
\hline ATCC 4617 & $(8)$ & $(8)$ & $(>8)$ & $(8)$ & (32) & $(>4)$ & $(>1)$ & $(>2)$ & $(>2)$ & $(>4)$ & $(>2)$ & $(1)$ \\
\hline
\end{tabular}

"_ no bioactivity - MIC > $1000 \mu \mathrm{g} / \mathrm{mL}$ 
The studied compounds showed differential effect towards the reference fungal strains belonging to Candida spp. (Table 4 and 5). Among them, $\mathbf{3 a}-\mathbf{3} \mathbf{f}$ and $\mathbf{3 k}$ substances showed very strong activity with $\mathrm{MIC}=0.24-7.81 \mu \mathrm{g} / \mathrm{mL}$ and $\mathrm{MFC}=0.48-62.5 \mu \mathrm{g} / \mathrm{mL}$ against Candida spp. strains, except $C$. glabrata ATCC 90030 . The high activity with very strong or strong effect towards these microorganisms exhibited also $\mathbf{3 g}$ and $\mathbf{3 h}$ compounds $(\mathrm{MIC}=7.81-15.62 \mu \mathrm{g} / \mathrm{mL}$ and $\mathrm{MFC}=15.62-62.5 \mu \mathrm{g} / \mathrm{mL})$. . . glabrata ATCC 90030 was less sensitive to the above substances. The minimal concentrations of $\mathbf{3 a}-\mathbf{3 e}$ and $3 \mathrm{~h}$ compounds, which inhibited growth of these strains were $62.5 \mu \mathrm{g} / \mathrm{mL}$. The highest effect towards C. glabrata showed $3 \mathbf{f}$ with MIC $=31.25 \mu \mathrm{g} / \mathrm{mL}$. In turn, MICs of $\mathbf{3 g}$ and $\mathbf{3 k}$ substances were $125 \mu \mathrm{g} / \mathrm{mL}$. These compounds $\mathbf{3 a}-\mathbf{3 h}$ and $\mathbf{3 k}$ showed good activity against $C$. glabrata and their MFC ranged from $125 \mu \mathrm{g} / \mathrm{mL}$ to $>1000 \mu \mathrm{g} / \mathrm{mL}$. The lowest activity against all reference Candida spp. exhibited two studied compounds: $\mathbf{3 i}$ and $3 \mathbf{j}$ with MIC $=125-500 \mu \mathrm{g} / \mathrm{mL}$ and $\mathrm{MFC} \geq 1000 \mu \mathrm{g} / \mathrm{mL}$.

Table 4. The activity data of compounds expressed as MIC $[\mu \mathrm{g} / \mathrm{ml}]$ against the reference strains of fungi. The standard antibiotic nystatin (NY) was used as positive control.

\begin{tabular}{cccccccccccccc}
\hline Species & \multicolumn{8}{c}{ MIC $[\mu \mathrm{g} / \mathrm{mL}$ of compounds and positive control } \\
\cline { 2 - 12 } & $\mathbf{3 a}$ & $\mathbf{3 b}$ & $\mathbf{3 c}$ & $\mathbf{3 d}$ & $\mathbf{3 e}$ & $\mathbf{3 f}$ & $\mathbf{3 g}$ & $3 \mathbf{h}$ & $\mathbf{3 i}$ & $\mathbf{3 j}$ & $\mathbf{3 k}$ & $\mathbf{N Y}$ \\
\hline $\begin{array}{c}\text { Candida albicans } \\
\text { ATCC 2091 }\end{array}$ & $\mathbf{1 . 9 5}$ & $\mathbf{0 . 2 4}$ & $\mathbf{0 . 9 8}$ & $\mathbf{7 . 8 1}$ & $\mathbf{0 . 2 4}$ & $\mathbf{3 . 9 1}$ & 15.62 & 7.81 & 250 & 500 & $\mathbf{3 . 9 1}$ & $\mathbf{0 . 2 4}$ \\
\hline $\begin{array}{c}\text { Candida albicans } \\
\text { ATCC 10231 }\end{array}$ & $\mathbf{0 . 9 8}$ & $\mathbf{0 . 9 8}$ & $\mathbf{0 . 4 8}$ & $\mathbf{1 . 9 5}$ & $\mathbf{0 . 2 4}$ & $\mathbf{0 . 4 8}$ & $\mathbf{7 . 8 1}$ & 15.62 & 125 & 250 & $\mathbf{7 . 8 1}$ & $\mathbf{0 . 4 8}$ \\
\hline $\begin{array}{c}\text { Candida parapsilosis } \\
\text { ATCC 2201 }\end{array}$ & $\mathbf{1 . 9 5}$ & $\mathbf{1 . 9 5}$ & $\mathbf{0 . 9 8}$ & $\mathbf{7 . 8 1}$ & $\mathbf{0 . 9 8}$ & $\mathbf{3 . 9 1}$ & 15.62 & $\mathbf{7 . 8 1}$ & 125 & 250 & $\mathbf{7 . 8 1}$ & $\mathbf{0 . 2 4}$ \\
\hline $\begin{array}{c}\text { Candida glabrata } \\
\text { ATCC 90030 }\end{array}$ & 62.5 & 62.5 & 62.5 & 62.5 & 62.5 & 31.25 & 125 & 62.5 & 250 & 250 & 125 & $\mathbf{0 . 2 4}$ \\
\hline $\begin{array}{c}\text { Candida krusei } \\
\text { ATCC 14243 }\end{array}$ & $\mathbf{1 . 9 5}$ & $\mathbf{0 . 9 8}$ & $\mathbf{0 . 4 8}$ & $\mathbf{1 . 9 5}$ & $\mathbf{0 . 9 8}$ & $\mathbf{3 . 9 1}$ & 15.62 & 15.62 & 125 & 250 & $\mathbf{7 . 8 1}$ & $\mathbf{0 . 2 4}$ \\
\hline
\end{tabular}

Concentrations indicating very strong activity (MIC $<10 \mu \mathrm{g} / \mathrm{mL}$ ) are marked with bolded cited.

In general, most of the newly synthesized compounds $\mathbf{3} \mathbf{a}-\mathbf{3 k}$ indicated fungicidal effect (MFC/MIC $=2-4)$, while the substances $\mathbf{3} \mathbf{f}, \mathbf{3 i}, \mathbf{3} \mathbf{j}$ and $\mathbf{3} \mathbf{k}$ had a fungicidal or fungistatic effect (MFC/MIC $>4$ ).

Table 5. The activity data of compounds expressed as MFC $[\mu \mathrm{g} / \mathrm{ml}]$ and MFC/MIC ratio against the reference strains of fungi. The standard antibiotic - nystatin (NY) was used as positive control.

\begin{tabular}{|c|c|c|c|c|c|c|c|c|c|c|c|c|}
\hline \multirow{2}{*}{ Species } & \multicolumn{12}{|c|}{ MFC $[\mu \mathrm{g} / \mathrm{mL}]$ and MFC/MIC ratio of compounds and positive control } \\
\hline & 3a & $3 b$ & $3 c$ & $3 d$ & $3 e$ & $3 f$ & $3 g$ & $3 h$ & $3 \mathbf{i}$ & $3 \mathbf{j}$ & $3 k$ & NY \\
\hline Candida albicans & 3.91 & 0.48 & 3.91 & 15.62 & 0.98 & 7.81 & 62.5 & 15.62 & 1000 & 1000 & 31.62 & 0.24 \\
\hline ATCC 2091 & $(2)$ & $(2)$ & $(4)$ & $(2)$ & $(4)$ & (2) & $(4)$ & $(2)$ & $(4)$ & $(2)$ & $(8)$ & (1) \\
\hline Candida albicans & 1.95 & 3.91 & 0.98 & 7.81 & 0.98 & 0.98 & 31.25 & 15.62 & $>1000$ & $>1000$ & 31.25 & 0.48 \\
\hline ATCC 10231 & (2) & (4) & (2) & (4) & $(4)$ & (2) & (4) & $(1)$ & $(>8)$ & $(>4)$ & $(4)$ & $(1)$ \\
\hline Candida parapsilosis & 3.91 & 3.91 & 3.91 & 15.62 & 3.91) & 15.62 & 62.5 & 31.25 & $>1000$ & $>1000$ & 31.25 & 0.48 \\
\hline ATCC 2201 & $(2)$ & $(2)$ & $(4)$ & $(2)$ & $(4)$ & $(4)$ & $(4)$ & $(4)$ & $(>8)$ & $(>4)$ & $(4)$ & $(2)$ \\
\hline Candida glabrata & 125 & 125 & 125 & 125 & 250 & 250 & 250 & 250 & $>1000$ & 1000 & 250 & 0.48 \\
\hline ATCC 90030 & (2) & (2) & (2) & (2) & (4) & (8) & (2) & (4) & $(>4)$ & $(4)$ & (2) & (2) \\
\hline Candida krusei & 3.91 & 1.95 & 1.95 & 7.81 & 3.91 & 7.81 & 62.5 & 31.25 & 1000 & 1000 & 62.5 & 0.24 \\
\hline ATCC 14243 & (2) & (2) & (4) & (4) & (4) & (2) & (4) & (2) & (8) & (4) & (8) & (1) \\
\hline
\end{tabular}




\subsubsection{Effect on Candida albicans Biofilm}

Due to the high antifungal activity of the most of novel compounds, additionally the effect of compounds $\mathbf{3 b}, \mathbf{3} \mathbf{c}$ and $\mathbf{3 e}$ on the biofilm of the reference strain C. albicans ATCC 10231 was also assayed. Antibiofilm activity was studied by measuring of the biofilm biomass and its metabolic activity after treatment with the mentioned above compounds. Effect on the biofilm-forming ability (and inhibition of the adhesion phase) was tested in the presence of three different concentrations $(1 / 8 \times \mathrm{MIC}, 1 / 4 \times \mathrm{MIC}$, and $1 / 2$ $x$ MIC). The biomasses of biofilms were determined by crystal violet (CV) assay, which is one of the most popular method to detect maintained adherence of cells. It is based on the staining of attached cells with CV dye, which binds to their proteins and DNA [35,48]. Cells that undergo cell death, under the influence of antifungals, lose their adherence and are subsequently lost from the population of cells, reducing the amount of CV staining in a culture [35]. The results showed that studied compounds in used concentrations $(\leq 1 / 2$ MIC) have no inhibitory effect on the adhesion phase and biofilm formation by the reference C. albicans ATCC 10231 strain.

Moreover, colorimetric tetrasolium salt (XTT) reduction assay was undertaken to examine the effect of newly synthesized compounds on viability of $C$. albicans cells within the biofilm and the metabolic activity of this structure. It relies on the reduction of yellow tetrazolium salt XTT by dehydrogenase enzymes of metabolically active cells yielding an orange-coloured, water-soluble formazan [49]. Live cells reduce the tetrazole ring and formazan is formed, which can be assessed visually and quantified spectrophotometrically [51]. The obtained results confirmed also no effect of these compounds on the metabolic activity of C. albicans ATCC 10231 biofilm at the same concentrations as used in CV assay. In the both studies OD obtained for each condition was comparable to the control .

The antibiofilm effect of these compounds was also tested towards mature biofilm of reference $C$. albicans strain. Biofilm biomass and the cellular metabolic activity were studied using the same methods as previously, by CV staining and XTT reduction assay, respectively. It was showed, that the newly synthesized derivatives have no eradication effect against mature biofilms at the concentration values corresponding to: MIC, 2 times and 8 times higher than the MIC for planktonic cells (Table 6), consistent with the prior observation that mature biofilms are more resistant to antifungal drugs [11].

In the case of metabolic activity assay, some very slight changes were observed on mature biofilm for compound $\mathbf{3 b}$. A slight decrease in this activity was observed at the higher concentration (8-fold higher than MIC for planktonic cells). In the case of remaining compounds, OD obtained for selected MIC value was comparable to the control.

Table 6. The effect of compounds on the metabolic activity of mature C. albicans biofilm (with XTT reduction assay).

\begin{tabular}{ccccc}
\hline \multirow{2}{*}{ Compound } & \multicolumn{4}{c}{ The effect on the metabolic activity of biofilm (OD) } \\
\cline { 2 - 5 } & MIC & $\mathbf{2}$ x MIC & $\mathbf{8}$ x MIC & Control \\
\hline $3 \mathrm{~b}$ & 2.03 & 1.9 & $\mathbf{1 . 7 6}$ & 2.07 \\
$3 \mathrm{C}$ & 2.07 & 2.06 & 1.97 & 2.07 \\
$3 \mathrm{e}$ & 2.07 & 2.07 & 2.07 & 2.07 \\
\hline
\end{tabular}

A slight decrease of metabolic activity of biofilm is marked with bolded cited.

\subsubsection{Membrane Permeability Assay}

Alteration of membrane permeability of C. albicans ATCC 10231 was also investigated using a CV assay (Table 7). Crystal violet which was generally poorly penetrated the membrane, could enter the damaged cell membrane. Cells treated with compounds stained, indicating changes in membrane permeability and cell death. In contrast, control cells, not treated with tested compounds, did not stain with $\mathrm{CV}$, indicating live cells with intact cell membranes [52] . In the case of compounds $\mathbf{3 b}, \mathbf{3} \mathbf{c}$, 
and 3e, an enhancement in the uptake of CV was observed. These compounds in higher concentrations increase the permeability of the membrane/cell wall of C. albicans strains and take up CV from the medium. The highest CV uptake - $28 \%$ was showed for compound $3 \mathbf{c}$ at concentration 8 times higher than MIC for planktonic cells. In the case of compounds $3 \mathbf{b}$ and $3 \mathbf{e}, \mathrm{CV}$ uptake was $11.4 \%$ and $1.8 \%$, respectively.

Table 7. The effect of compounds on the cell membrane of C. albicans ATCC 10231.

\begin{tabular}{cccc}
\hline \multirow{2}{*}{ Compound } & \multicolumn{3}{c}{ The effect on the cell membrane $(\%$ of CV uptake) } \\
\cline { 2 - 4 } & MIC & $\mathbf{2}$ MIC & $\mathbf{8}$ MIC \\
\hline $3 b$ & 0 & 1.5 & 11.4 \\
$3 \mathrm{c}$ & 0 & 4.0 & 28.0 \\
$3 \mathrm{e}$ & 0 & 1.0 & 1.8 \\
\hline
\end{tabular}

\subsubsection{Mode of action with Sorbitol and Ergosterol Assay}

The mode of action of the newly synthesized compounds $\mathbf{3 b}, \mathbf{3} \mathbf{c}$, and $\mathbf{3 e}$, presented in Table 8, was tested in order to define whether their anticandidal effect involved a direct interaction with the cell wall structure of $C$. albicans (via testing with sorbitol) and/or with the ion permeability of the membrane of this organism (via the test with ergosterol) [39-42,53]. Sorbitol has an osmoprotectant function and was used to stabilize fungi protoplasts. Cells protected with sorbitol may grow in the presence of fungal cell wall inhibitors, whereas growth would be inhibited in the absence of sorbitol. This effect is detected by increases in the MIC value as observed in medium with sorbitol as compared to the MIC value in medium without sorbitol $[39-42,53]$. The obtained results showed that there are some differences between MIC values of the tested compounds against reference $C$. albicans strains in either the absence or presence of sorbitol. MIC values of compounds $\mathbf{3 b}$ and $3 \mathbf{e}$ for C. albicans ATCC 10231 strain increased 8-fold and even 32 -fold for compound $3 \mathrm{c}$ in the presence of sorbitol. Therefore, we can suppose that synthesized compounds involved a direct interaction with the cell wall structure of $C$. albicans

Considering this possible fungal cell membrane interference of these compounds, it was tested to investigate their ability to form complexes with ergosterol. Ergosterol is the major sterol component present in the plasma membrane of fungi and plays the same role in fungal membranes that cholesterol plays in mammalian cell. The activity of the newly thiazole derivatives may be also caused by binding to fungal sterol, because their MIC values in the medium with exogenous ergosterol were 32 times or 64 times higher compared with the ergosterol-free experiment. The exogenous ergosterol prevent the binding to ergosterol in the fungal membranes. Consequently, MIC increase for these compounds occur because only increased product concentration in the medium might assure interaction with ergosterol in the fungal membranes [39-42].

As can be seen, the MIC values of nystatin (used as control) in mediums with and without sorbitol, were identical, suggesting that this antibiotic does not act by inhibiting fungal cell wall synthesis. In turn, it was observed a 16-fold increase in the MIC values after the addition of ergosterol. This indicates that the mechanism of action of nystatine involves complexation with ergosterol.

Table 8. The increase in the MIC values (x MIC) of compounds in the presence of sorbitol $(0.8 \mathrm{M})$ and ergosterol $(400 \mu \mathrm{g} / \mathrm{mL})$ against $C$. albicans ATCC 10231 . The standard antibiotic - nystatin (NY) was used as control.

\begin{tabular}{ccc}
\hline Compound & \multicolumn{2}{c}{ The increase in the MIC values (x MIC) } \\
\cline { 2 - 3 } & with sorbitol & with ergosterol \\
\hline $3 \mathrm{~b}$ & $\times 8$ & $\times 32$ \\
$3 \mathrm{c}$ & $\times 32$ & $\times 64$ \\
$3 \mathrm{e}$ & $\times 8$ & $\times 64$
\end{tabular}


NY $\times 1 \quad \times 16$

\subsection{Cytotoxic activity}

In the next stage of our research, the toxicity of the newly synthesized compounds was assayed. This is a very important study which determines whether the tested compounds will be suitable for further clinical investigation [54]. To demonstrate that these compounds are safe for host cells, we decided to investigate their cytotoxic effect on normal human lung fibroblasts using an MTT assay. In this experiment CCD-11Lu cell lines were exposed to five different concentrations of tested compounds $3 \mathbf{b}, \mathbf{3 c}$ and $\mathbf{3 e}$ for $24 \mathrm{~h}, 48 \mathrm{~h}$ and $72 \mathrm{~h}$. The obtained results indicate that these compounds do not show significant cytotoxic properties towards human lung fibroblasts. The cell viability percentage was shown in Table 9. It was observed that the viability of normal cells after 24-hour, 48-hour and 72-hour exposure to the tested compounds at concentrations of $0.25,0.5,1,10$ and $25 \mu \mathrm{g} / \mathrm{mL}$ varied slightly with time and dose and was similar. However, the highest mean cell viability percentage was with the lowest substance concentration (about $100 \%$ viability at $0.25 \mu \mathrm{g} / \mathrm{mL}$ ). In turn, in the case of compound $3 \mathbf{b}$ at concentration $25 \mu \mathrm{g} / \mathrm{mL}$ cell viability was $86 \%$. These results confirm that, antifungal effect of the new compounds against reference C. albicans strains was observed at their non-cytotoxic concentrations.

Table 9. Viability (\%) of normal human lung fibroblasts (CCD-11Lu) cell exposed to the tested compounds.

\begin{tabular}{ccccccc}
\hline Compound & $\mathrm{T}$ & \multicolumn{5}{c}{ Cell viability [\%] exposed to compounds in the concentrations } \\
\cline { 3 - 7 } & {$[\mathbf{h}]$} & $\mathbf{0 . 2 5} \boldsymbol{\mu} \mathbf{g} / \mathbf{m L}$ & $\mathbf{0 . 5} \boldsymbol{\mu g} / \mathbf{m L}$ & $\mathbf{1} \boldsymbol{\mu g} / \mathbf{m L}$ & $\mathbf{1 0} \boldsymbol{\mu g} / \mathbf{m L}$ & $\mathbf{2 5} \boldsymbol{\mu g} / \mathbf{m L}$ \\
\hline $3 \mathrm{~b}$ & 24 & $102.08 \pm 5.10$ & $97.56 \pm 4.88$ & $96.00 \pm 4.80$ & $92.80 \pm 4.64$ & $86.45 \pm 4.32$ \\
\cline { 2 - 7 } & 48 & $102.72 \pm 5.14$ & $99.71 \pm 4.99$ & $99.85 \pm 4.99$ & $97.36 \pm 4.87$ & $100.46 \pm 5.02$ \\
\cline { 2 - 7 } & 72 & $103.66 \pm 5.18$ & $99.77 \pm 4.99$ & $103.55 \pm 5.18$ & $100.82 \pm 5.04$ & $100.60 \pm 5.03$ \\
\hline $3 \mathrm{c}$ & 24 & $100.52 \pm 5.03$ & $103.26 \pm 5.16$ & $108.16 \pm 5.41$ & $102.36 \pm 5.12$ & $111.81 \pm 5.59$ \\
\cline { 2 - 7 } & 48 & $100.00 \pm 5.00$ & $109.27 \pm 5.46$ & $105.28 \pm 5.26$ & $104.83 \pm 5.24$ & $102.40 \pm 5.12$ \\
\hline $3 \mathrm{e}$ & 72 & $100.34 \pm 5.02$ & $105.61 \pm 5.28$ & $99.88 \pm 4.99$ & $95.35 \pm 4.77$ & $96.26 \pm 4.81$ \\
\hline & 24 & $103.00 \pm 5.15$ & $95.88 \pm 4.79$ & $98.74 \pm 4.94$ & $105.73 \pm 5.29$ & $94.61 \pm 4.73$ \\
\hline & 48 & $100.14 \pm 5.01$ & $92.53 \pm 4.63$ & $97.08 \pm 4.85$ & $106.54 \pm 5.33$ & $109.52 \pm 5.48$ \\
\hline & 72 & $100.48 \pm 5.02$ & $100.41 \pm 5.02$ & $97.78 \pm 4.89$ & $102.99 \pm 5.15$ & $98.95 \pm 4.95$ \\
\hline
\end{tabular}

\subsection{Hemolytic activity}

In the present studies the erythrocyte model was used to assess the hemolytic activity of compounds $\mathbf{3 b}, \mathbf{3} \mathbf{c}$ and $\mathbf{3 e}$. Hemolysis is due to red blood cells destruction which resulted from lysis of their membrane lipid bilayer [44,45]. To estimate the relative hemolytic potential of the tested compounds, the appropriate controls: $100 \%$ erythrocyte lysis using 1\% Triton X-100 (positive control) and no lysis in DMSO (negative control) were used. As presented in Table 10, the concentrations with a value of MIC, 2-fold, 5-fold and 10-fold higher than MIC of the studied compounds not exerting any hemolytic effects. The percentage of lysed red blood cells ranged from 0.01 to 1.11. In these concentrations, the compounds are not toxic to erythrocytes. The present results showed, like the cytotoxicity studies, that the new compounds indicated anticandidal effect at their non-cytotoxic concentrations.

Table 10. Hemolytic effect (\% of hemolysis) of compounds.

\begin{tabular}{cccccc}
\hline & \multicolumn{3}{c}{ \% of lysed erythrocytes exposed to compounds in the concentrations } \\
\cline { 2 - 5 } Compound & MIC & $2 \times$ MIC & $5 \times$ MIC & $10 \times$ MIC & Triton \\
& & & & $X-100(1 \%)$ \\
\hline
\end{tabular}




\begin{tabular}{|c|c|c|c|c|c|}
\hline $3 b$ & 0.16 & 0.01 & 0.17 & 0.39 & \multirow{3}{*}{100} \\
\hline $3 c$ & 0.19 & 0.23 & 0.01 & 0.09 & \\
\hline $3 e$ & 0.28 & 0.38 & 0.85 & 1.11 & \\
\hline
\end{tabular}

\section{Discussion}

It is worth notifying that the treatment of candidiasis, especially invasive disease, is often ineffective, since the list of antifungals is very limited, while many of them have been extensively used leading to the development of antifungal resistance [55]. Therefore, there is a strong need to search for new antifungals. Prompt by the above mentioned fact in this research the novel dicyclopropyl-thiazole compounds were designed, synthesized and characterized by physico-chemical parameters together with their investigation for in vitro antimicrobial effect.

The obtained results showed that most of the studied novel compounds possessed very strong antifungal effect (MIC $=0.24-7.81 \mu \mathrm{g} / \mathrm{mL}$ ). The Candida spp. strains were especially sensitive to compounds $\mathbf{3 a}-\mathbf{3 f}$ and $\mathbf{3 k}$ (with except of $C$. glabrata ATCC 90030). Moreover, almost all substances showed fungicidal effect (MFC/MIC $=2-4)$, which is very beneficial from a therapeutic point of view. Due to the high antifungal activity of these compounds, some of them, namely $\mathbf{3 b}, \mathbf{3} \mathbf{c}$, and $\mathbf{3 e}$ were used for further detailed research. Because the predominant cause of all types of candidiases is Candida albicans, for these studies reference C. albicans ATCC 10231 strain was used. The antibiofilm activity and mode of action together with the effect on the membrane permeability in $C$. albicans were investigated.

It is known that fungal cell adhesion and biofilm formation are the key points for the pathogenesis as well as antifungal treatment [49]. The ability to evaluate the compounds activity during growth of biofilm and against mature biofilm is interesting for the investigation of resistance mechanisms and novel antifungal therapies [36,49]. The obtained results showed that newly synthesized dicyclopropyl-thiazole derivatives, although they had a strong antifungal effect, have no inhibitory effect (at 1/2 $\times$ MIC) and eradication effect (at $8 \times \mathrm{MIC}$ ) towards biofilm-forming and the mature structure, respectively. Moreover, only for compound $\mathbf{3 b}$ slight decrease in metabolic activity of mature biofilm (at 8-fold higher MIC) was observed. It is worth adding that cells in biofilms are much better protected against noxious agents than free-living cells. From a medical viewpoint, the most critical feature of biofilm growth is the development of antifungal insensitivity by the yeasts that constitute the biofilm. The elimination of mature biofilms presents a therapeutic challenge in the management of device-associated Candida infections. Novel drug targets and the development of new antifungal agents for the treatment of the biofilm-associated recalcitrant infections are therefore of interest $[36,40]$.

Studying the potential mechanisms of action of the compounds $3 \mathbf{b}, 3 \mathbf{c}$, and $3 \mathbf{e}$, it was of interest to check whether their antifungal activity involved a direct interaction with the cell wall structure of C. albicans and/or with the ion permeability of the membrane of this organism [39]. The sorbitol assay is based on acting this compound as osmoprotector which stabilize fungi protoplasts and in consequence antifungal effects of cell wall inhibitors are reversed in media containing sorbitol. This effect is detected by the increase in the MIC value observed in medium with sorbitol as compared to the MIC value in medium without sorbitol. The obtained results showed that there were some differences between MIC of the tested compounds against reference C. albicans strains in the absence or presence of sorbitol. MIC values of compounds $\mathbf{3 b}$ and $\mathbf{3 e}$ for reference $C$. albicans strain increased 8 times and even 32 times for compound $3 \mathrm{c}$ in the presence of sorbitol. These data suggest that the mode of action of the novel thiazole derivatives may be related to action within the fungal cell wall structure

Moreover, given the possible interference of these compounds with fungal cell membranes, their ability to form complexes with ergosterol was investigated. Ergosterol as a major sterol component presents in the plasma membrane of fungi and plays the 
same role in fungal membranes that cholesterol plays in mammalian cell [39-42]. The activity of the novel thiazole derivatives may be also caused by binding to fungal sterol, because their MIC values in the medium with exogenous ergosterol were 32-fold or 64-fold higher compared with the ergosterol-free medium. The exogenous ergosterol prevent the binding to ergosterol in the fungal membranes. Consequently, MIC increase for these compounds occurs because only increased product concentration in the medium might assure interaction with ergosterol in the fungal membranes [39-42]. In the case of nystatin used as control agents with a known mechanism of action involving complexation with ergosterol, it was showed a 16-fold increase in the MIC values in the presence of ergosterol.

In our research alteration of membrane permeability of yeasts after treated with tested compounds was also determined. Membrane permeability was investigated by the uptake of crystal violet (CV) that penetrated only compromised cell membranes, resulting in cell staining. In turn, live cells with intact cell membranes, not treated with tested compounds, did not stain with CV. The highest CV uptake $-28 \%$ was showed for compound $3 \mathbf{c}$ at concentration 8 times higher than MIC.

Cytotoxicity and safety assessment of potential medicinal components are very important parameters that need to be also evaluated. Therefore, the next stage of this study was to determine in vitro cytotoxicity effect of the selected compounds, namely $\mathbf{3 b}$, $3 \mathbf{c}$ and $3 \mathbf{e}$ on normal human lung fibroblasts using MTT test. Cell culture techniques are useful for the evaluation of the toxicity of different compounds or materials. The results obtained from these in vitro assays might be indicative of the effects observed in vivo [56]. Amongst in vitro assays, cytotoxicity tests are simple, reproducible, inexpensive to perform, and suitable for evaluation of basic biologic properties [43]. These studies provide also a significant amount of information can be conducted under controlled conditions and may elucidate the mechanisms of cellular toxicity [43,57,58]. Several methods are available for cytotoxicity testing and among them, the MTT-based colorimetric assay is a standard method. This test indicates the number of viable cells and the level of metabolic activity in a sample [43]. The concentrations of the tested compounds and exposure time are very important parameter in cytotoxicity assay. According to Basak et al. [43], the absorption value obtained with the control cells was adjusted to $100 \%$ viability. Cytotoxicity was rated based on cell viability relative to the control group: non-cytotoxic $>90 \%$, slightly cytotoxic $60 \%-90 \%$, moderately cytotoxic $30 \%-59 \%$ and severely cytotoxic $<30 \%$ cell viability. In turn, according to data presented by Kazak et al. [57], cell viability lower than $70 \%$ indicates that the material has cytotoxic potential. In present study no cytotoxicity (cell viability >90\%) was found for all concentrations of the tested compounds even after exposing for $72 \mathrm{~h}$. The highest viability percentage for normal human lung fibroblast cells $(100 \%)$ was found in the lowest concentrations of compounds $(0.25 \mu \mathrm{g} / \mathrm{mL})$. In turn, at concentration $25 \mu \mathrm{g} / \mathrm{mL}$ of compound $\mathbf{3 b}$ after 24 -hour exposure was observed $86.45 \%$ cell viability. On the basis of these results, no cytotoxic activity of this compound can be confirmed.

In the present studies, the red blood cells (RBCs) were also used to assess the influence of the compounds $\mathbf{3 b}, \mathbf{3} \mathbf{c}$ and $3 \mathbf{e}$ on their cell membrane. The lysis of membrane lipid bilayer of RBCs is relates with concentration and potency of the studied agents. Hemolysis refers to the disruption of RBCs, and the assay detects the leaking of intracellular contents including hemoglobin. The extent of hemolysis was estimated from the amount of the extracellular hemoglobin [42,59]. Many studies have reported that in vitro hemolysis assays have good correlations with in vivo toxicity. We observed no hemolytic effect of these compounds at concentrations up to 10 times higher than MIC. The erythrocyte lysis assay confirmed also that newly synthesized derivatives showed antifungal effect at their non-cytotoxic concentrations towards reference $C$. albicans strains. Similar antifungal activity of $\mathbf{3 b}, \mathbf{3} \mathbf{c}$ and $\mathbf{3 e}$ compounds found confirmation in their close to each other $\Delta E$ values.

\section{Conclusions}


The obtained results showed that the most of newly synthesized dicyclopropyl-thiazole derivatives indicated strong antifungal effect at non-cytotoxic concentrations against the reference Candida spp. strains. These compounds increased the permeability of the membrane/cell wall of yeasts and their mode of activity may be related to action within the fungal cell wall structure and/or within the cell membrane. It was observed that their antifungal action is not related with effect on the biofilm structure and its metabolic activity. These compounds represent a very promising group of antifungals for further preclinical studies.

Author Contributions: Concept and supervision over the project, A.B., A.M. and K.Z.Ł.; antimicrobial activity and mode of action, A.B.; the synthesis and spectroscopic characterization, A.Ba. and K.Z.Ł; quantum chemistry calculation and analysis of the data, A.B.-Ł.; cytotoxic activity, A.Ma.; antibiofilm activity, M.J.; hemolytic activity, M.M.; the manuscript preparation, A.B., AM and K.Z.E. All authors have read and agreed to the published version of the manuscript.

Funding: This study was supported by the Nicolaus Copernicus University (project No. WF 540/2020) and the Medical University (project No. DS30/2018-2020).

Conflicts of Interest: The authors declare no conflict of interest.

\section{References}

1. Houšt', J.; Spížek, J.; Havlíček, V. Antifungal Drugs. Metabolites 2020, 10:106. doi: 10.3390/metabo10030106

2. Pristov, K.E.; Ghannoum, M.A. Resistance of Candida to azoles and echinocandins worldwide. Clin Microbiol Infect 2019, 25, 792-798. doi: 10.1016/j.cmi.2019.03.028

3. Biernasiuk, A.; Kawczyńska, M.; Berecka-Rycerz, A.; Rosada, B.; Gumieniczek, A.; Malm, A.; Dzitko, K.; Łączkowski, K.Z. Synthesis, antimicrobial activity, and determination of the lipophilicity of ((cyclohex-3-enylmethylene) hydrazinyl)thiazole derivatives. Med Chem Res 2019, 28, 2023-2036.

4. Karpiński, T.M. Essential oils of Lamiaceae family plants as antifungals. Biomolecules 2020, 10, 103-138. doi:10.3390/biom10010103

5. Limon, J.L.; Skalski, J.H.: Underhill, D.M. Commensal fungi in Health and Disease. Cell Host Microbe 2017, 22 (2), 156-165.

6. Roemer,T.; Krysan, D.J. Antifungal drug development: challenges, unmet clinical needs, and new approaches. Cold Spring Harb Perspect Med 2014 pii:a019703. doi: 10.1101/cshperspect.a019703

7. Turecka, K.; Chylewska, A.; Kawiak, A.; Waleron, K.F. Antifungal activity and mechanism of action of the Co(III) coordination complexes with diamine chelate ligands against reference and clinical strains of Candida spp. Front Microbiol 2018, 9, 1954-1607. doi: $10.3389 /$ fmicb.2018.01594

8. Silva, S.; Rodrigues, C.F.; Araújo, D.; Rodrigues, M.E.; Henriques, M. Candida species biofilms' antifungal resistance. J Fungi 2017, 3, 8-24. doi: 10.3390/jof3010008

9. Sun, L.; Liao, K.; Wang, D. Effects of magnolol and honokiol on adhesion, yeast-hyphal transition, and formation of biofilm by Candida albicans. PLoS One 2015, 10:e117695. doi: 10.1371/journal.pone.0117695

10. Nett, J.E.; Cain, M.T.; Crawford, K.; Andes, D.R. Optimizing a Candida biofilm microtiter plate model for measurement of antifungal susceptibility by tetrazolium salt assay. J Clin Microbiol 2011, 49, 1426-33.

11. Kim, D.J.; Lee, M.W.; Choi, J.S.; Lee, S.G.; Park, J.Y.; Kim, S.W. Inhibitory activity of hinokitiol against biofilm formation in fluconazole-resistant Candida species. PLoS ONE 2017, 12 (2): e0171244. doi:10.1371/journal.pone.0171244

12. Ali, S.H.; Sayed, A.R. Review of the synthesis and biological activity of thiazoles. Synth Commun 2021, 51, 670-700.

13. Borcea, A.-M.; Ionut, I.; Crisan, O.; Oniga, O. An overview of the synthesis and antimicrobial. Molecules 2021, 26, 624.

14. Lin, Y.; Fan, H.; Li, Y.; Zhan, X. Thiazole-based organic semiconductors for organic electronics. Adv. Mater. 2012, 24, 3087-3106.

15. Lino, C.I.; de Souza, I.G.; Borelli, B.A.; Matos, T.T.S.; Teixeira, I.N.S.; Ramos, J.P.; de Souza Fagundes, E.M.; de Oliveira Fernandes, P.; Maltarollo, V.G.; Johann, S.; de Oliveira, R.B. Synthesis, molecular modeling studies and evaluation of antifungal activity of a novel series of thiazole derivatives. Eur. J. Med. Chem. 2018, 151, 248-260. 
16. Secci, D. Bizzarri, B.; Bolasco, A.; Carradori, S.; D'Ascenzio, M.; Rivanera, D.; Mari, E.; Polletta, L.; Zicari, A. Synthesis, anti-Candida activity, and cytotoxicity of new (4-(4-iodophenyl)thiazol-2-yl)-hydrazine derivatives. Eur. J. Med. Chem. 2012, 53, 246-253.

17. Kamat, V.; Santosh, R.; Poojary, B.; Nayak, S.P.; Kumar, B.K.; Sankaranarayanan, M.; Faheem; Khanapure, S.; Barretto, D.A.; Vootla, S.K.; Pyridine- and thiazole-based hydrazides with promising anti-inflammatory and antimicrobial activities along with their in silico studies. ACS Omega 2020, 5, 25228-25239

18. Yu, B.; Zhou, S.; Cao, L.; Hao, Z.; Yang, D.; Guo, X.; Zhang, N.; Bakulev, V.A.; Fan, Z. Design, Synthesis, and evaluation of the antifungal activity of novel pyrazole-thiazole carboxamides as succinate dehydrogenase inhibitors. J. Agric. Food Chem. 2020, 68, 7093-7102.

19. Piechowska, K.; Świtalska, M.; Cytarska, J.; Jaroch, K.; Łuczykowski, K.; Chałupka, J.; Wietrzyk, J.; Misiura, K.; Bojko, B.; Kruszewski, S.; Łączkowski, K.Z. Discovery of tropinone-thiazole derivatives as potent caspase 3/7 activators, and noncompetitive tyrosinase inhibitors with high antiproliferative activity: Rational design, one-pot tricomponent synthesis, and lipophilicity determination. Eur. J. Med. Chem. 2019, 175, 162-171.

20. Gomha, S.M.; Edrees, M.M.; Altalbawy, F.M.A. Synthesis and characterization of some new bis-pyrazolyl-thiazoles incorporating the thiophene moiety as potent anti-tumor agents Int. J. Mol. Sci. 2016, 17, 1499.

21. Łączkowski, K.Z.; Anusiak, J.; Świtalska, M.; Dzitko, K.; Cytarska, J.; Baranowska-Łączkowska, A.; Plech, T.; Paneth, A.; Wietrzyk, J.; Białczyk, J. Synthesis, molecular docking, ctDNA interaction, DFT calculation and evaluation of antiproliferative and anti-Toxoplasma gondii activities of 2,4-diaminotriazine-thiazole derivatives. Med. Chem. Res. 2018, 27, $1131-1148$.

22. Siddiqui, A.A.; Partap, S.; Khisal, S.; Yar, M.S.; Mishra, R. Synthesis, anti-convulsant activity and molecular docking study of novel thiazole pyridazinone hybrid analogues. Bioorg. Chem. 2020, 99, 103584.

23. Salar, U.; Khan, K.M.; Chigurupati, S.; Syed, S.; Vijayabalan, S.; Wadood, A.; Riaz, M.; Ghufran, M.; Perveen, S. New hybrid scaffolds based on hydrazinyl thiazole substituted coumarin; As novel leads of dual potential; in vitro $\alpha$-amylase inhibitory and antioxidant (DPPH and ABTS radical scavenging) activities. Med. Chem. 2019, 15, 87-101.

24. Konno, S.; Thanigaimalai, P.; Yamamoto, T.; Nakada, K.; Kakiuchi, R.; Takayama, K.; Yamazaki, Y.; Yakushiji, F.; Akaji, K.; Kiso, Y.; Kawasaki, Y.; Chen, S.-E.; Freire, E.; Hayashi, Y. Design and synthesis of new tripeptide-type SARS-CoV 3CL protease inhibitors containing an electrophilic arylketone moiety. Bioorg. Med. Chem, 2013, 21, 412-424.

25. Łączkowski, K.Z.; Motylewska, K.; Baranowska-Łączkowska, A.; Biernasiuk, A.; Misiura, K.; Malm, A,; Fernandez, B. Synthesis, antimicrobial evaluation and theoretical prediction of NMR chemical shifts of thiazole and selenazole derivatives with high antifungal activity against Candida spp. J. Mol. Struct. 2016, 1108, 427-437.

26. Talele, T.T. The "cyclopropyl fragment" is a versatile player that frequently appears in preclinical/clinical drug molecules. J. Med. Chem. 2016, 59, 8712-8756.

27. Bauer, M.R.; Di Fruscia, P.; Lucas, S.C.C.; Michaelides, I.N.; Nelson, J.E.; Storer, R.I.; Whitehurst, B.C. Put a ring on it: application of small aliphatic rings in medicinal chemistry. RSC Med. Chem. 2021, doi.org/10.1039/D0MD00370K.

28. Łączkowski, K.Z.; Konklewska, N.; Biernasiuk, A.; Malm, A.; Sałat, K.; Furgała, A.; Dzitko, K.; Bekier, A.; Baranowska-Łączkowska, A.; Paneth, A. Thiazoles with cyclopropyl fragment as antifungal, anticonvulsant, and anti-Toxoplasma gondii agents: synthesis, toxicity evaluation, and molecular docking study. Med. Chem. Res. 2018, 27, 2125-2140.

29. Biernasiuk, A.; Berecka-Rycerz, A.; Gumieniczek, A.; Malm, M.; Łączkowski, K.Z.; Szymańska, J.; Malm, A. The newly synthesized thiazole derivatives as potential antifungal compounds against Candida albicans. Appl. Microbiol. Biotechnol. 2021 (submitted).

30. Parr, R.G.; Pearson, R.G. Absolute hardness: companion parameter to absolute electronegativity. J. Am. Chem. Soc. 1983, 105, 7512-7516. 
31. European Committee for Antimicrobial Susceptibility Testing (EUCAST) Determination of minimum inhibitory concentrations (MICs) of antibacterial agents by broth dilution. EUCAST discussion document E. Dis 5.1, Clin Microbiol Infect 2003, 9, 1-7.

32. Clinical and Laboratory Standards Institute. Reference method for broth dilution antifungal susceptibility testing of yeasts. M27-S4. Clinical and Laboratory Standards Institute, Wayne, PA, USA, 2012.

33. O'Donnell, F.; Smyth, T.J.; Ramachandran, V.T.; Smyth, W.F. A study of the antimicrobial activity of selected synthetic and naturally occurring quinolones. Int J Antimicrob Agents 2010, 35, 30-38. doi: 10.1016/j.ijantimicag.2009.06.031.

34. Wiegand, I.; Hilpert, K.; Hancock, R.E.W. Agar and broth dilution methods to determine the minimal inhibitory concentration (MIC) of antimicrobial substances, Nat Protoc 2008, 3, 163-175. doi: 10.1038/nprot.2007.521.

35. Feoktistova, M.; Geserick, P.; Leverkus, M. Crystal violet assay for determining viability of cultured cells. Cold Spring Harb Protoc 2016, 1, (4): pdb.prot087379.

36. Nett, J.E.; Cain, M.T.; Crawford, K.; Andes, D.R. Optimizing a Candida biofilm microtiter plate model for measurement of antifungal susceptibility by tetrazolium salt assay. J Clin Microbiol 2011, 49, 1426-33.

37. Ramage, G.; Vande Walle, K.; Wickes, B.L.; Lopez-Ribot, J.L. Standardized method for in vitro antifungal susceptibility testing of Candida albicans biofilms. Antimicrob Agents Chemother 2001, 45, 2475-9.

38. Lee, H.S.; Kim, Y. Antifungal activity of Salvia miltiorrhiza against Candida albicans is associated with the alteration of membrane permeability and (1,3)-b-D-glucan synthase activity. J Microbiol Biotechnol 2016, 26, 610-617.

39. de Oliveira, Filho, A.A.; de Oliveira, H.M.B.F.; de Sousa, J.P.; Meireles, D.; de Azevedo, Maia, G.L. Filho, J.M.B.; Lima, E.O. In vitro anti-Candida activity and mechanism of action of the flavonoid isolated from Praxelis clematidea against Candida albicans species. J App Pharm Sci 2016, 6:,66-69.

40. Leite, M.C.; Bezerra, A.P.; de Sousa, J.P.; Guerra, F.Q.; Lima, E. de O. Evaluation of antifungal activity and mechanism of action of citral against Candida albicans. Evid Based Complement Alt Med 2014, 378280. doi: 10.1155/2014/378280

41. Lima, I.O.; de Medeiros, Nóbrega, F.; de Oliveira, W.A.; Lima, E. de O.; Menezes, E.A.; Cunha, F.A.; Diniz, M. de F.M. Anti-Candida albicans effectiveness of citral and investigation of mode of action. Pharm Biol 2012, 50, 1536-1541. doi: 10.3109/13880209.2012.694893

42. Turecka, K.; Chylewska, A.; Kawiak, A.; Waleron, K.F. Antifungal activity and mechanism of action of the Co(III) coordination complexes with diamine chelate ligands against reference and clinical strains of Candida spp. Front Microbiol 2018, 9, $1954-1607$. doi: 10.3389/fmicb.2018.01594

43. Basak, V.; Bahar, T.E.; Emine, K.; Yelda, K.; Mine, K.; Figen, S.; Rustem, N. Evaluation of cytotoxicity and gelatinases activity in 3T3 fibroblast cell by root repair materials, Biotechnol. Biotechnol. Equip. 2016, 30:5, 984-990, doi: 10.1080/13102818.2016.1192960

44. Han, J.; Jyoti, M.A.; Song, H.Y.; Jang, W.S. Antifungal activity and action mechanism of histatin 5-halocidin hybrid peptides against Candida ssp. Plos One 2016, 11:e0150196. doi: 10.1371/journal.pone.0150196

45. Zohra, M.; Fawzia, A. Hemolytic activity of different herbal extracts used in Algeria. Int J Pharm Sci Res 2014, 5, 495-500.

46. Frisch, M.J.; Trucks, G.W.; Schlegel, H.B.; Scuseria, G.E.; Robb, M.A.; Cheeseman, J.R.; Scalmani, G.; Barone, V.; Mennucci, B.; Petersson, G.A.; Nakatsuji, H.; Caricato, M.; Li, X.; Hratchian, H.P.; Izmaylov, A.F.; Bloino, J.; Zheng, G.; Sonnenberg, J.L.; Hada, M.; Ehara, M.; Toyota, K.; Fukuda, R.; Hasegawa, J.; Ishida, M.; Nakajima, T.; Honda, Y.; Kitao, O.; Nakai, H.; Vreven, T.; Montgomery, Jr J.A.; Peralta, J.E.; Ogliaro, F.; Bearpark, M.; Heyd, J.J.; Brothers, E.; Kudin, K. N.; Staroverov, V.N.; Kobayashi, R.; Normand, J.; Raghavachari, K.; Rendell, A.; Burant, J.C.; Iyengar, S.S.; Tomasi, J.; Cossi, M.; Rega, N.; Millam, N.J.; Klene, M.; Knox, J.E.; Cross, J.B.; Bakken, V.; Adamo, C.; Jaramillo, J.; Gomperts, R.; Stratmann, R.E.; Yazyev, O.; Austin, A.J.; Cammi, R.; Pomelli, C.; Ochterski, J.W.; Martin, R.L.; Morokuma, K.; Zakrzewski, V.G.; Voth, G.A.; Salvador, P.; Dannenberg, J.J.; Dapprich, S.; Daniels, A.D.; Farkas, Ö.; Foresman, J.B.; Ortiz, J.V.; Cioslowski, J.; Fox, D.J. gaussian 09, Revision C.01. Gaussian, Inc., Wallingford, 2009.

47. Dennington, R.; Keith, T.; Millam, J. Gauss View, Version 5. Semichem Inc., Shawnee Mission, 2009.

48. Corte, L.; Pierantoni, D.C.; Tascini, C.; Roscini, L.; Cardinali, G. Biofilm specific activity: a measure to quantify microbial biofilm. Microorganisms 2019, 7, 73-87. doi:10.3390/microorganisms7030073

49. Nordin, M.A.F.; Razak, F.A.; Himratul-Aznita, W.H. Assessment of antifungal activity of bakuchiol on oral-associated Candida spp. Evid-Based Compl Alt Med 2015, Article ID 918624, http://dx.doi.org/10.1155/2015/918624

50. Taff, H.T.; Nett, J.E.; Andes, D.R. Comparative analysis of Candida biofilm quantitation assays. Med Mycol 2012, 50 (2), $214-218$. doi: 10.3109/13693786.2011.580016 
51. Knight, S.A.B.; Dancis, A. Reduction of ,3-bis(2-methoxy-4-nitro-5-sulfophenyl)-2H-tetrazolium-5-carboxanilide inner salt (XTT) is dependent on CaFRE10 ferric reductase for Candida albicans grown in unbuffered media. Microbiology 2006, 152, 2301-2308. DOI 10.1099/mic.0.28843-0

52. Guo, N.; Gai, Q.-Y.; Jiao, J.; Wang, W.; Zu, Y.-G.; Fu, Y.-J. Antibacterial activity of Fructus Forsythia essential oil and the application of EO-loaded nanoparticles to food-borne pathogens. Foods 2016, 5, 73-86. doi:10.3390/foods5040073

53. Castro, R.D.; Lima, E.O. Anti-Candida activity and chemical composition of Cinnamomum zeylanicum blume essential oil. Braz Arch Biol Technol 2013, 56, 749-755.

54. Łączkowski, K.Z.; Konklewska, N.; Biernasiuk, A.; Malm, A.; Sałat, K.; Furgała, A.; Dzitko, K.; Bekier, A.; Baranowska-Łacczkowska. A.; Paneth. A. Thiazoles with cyclopropyl fragment as antifungal, anticonvulsant, and anti-Toxoplasma gondii agents: synthesis, toxicity evaluation, and molecular docking study. Med Chem Res 2018, 27, $2125-2140$.

55. Gong, Y.; Liu, W.; Huang, X.; Hao, L.; Li, Y.; Sun, S. Antifungal activity and potential mechanism of N-butylphthalide alone and in combination with fluconazole against Candida albicans. Front. Microbiol. 2019, 10: 1461. doi: 10.3389/fmicb.2019.01461

56. Marins, J.S.R.; Sassone, L.M.; Fidel, S.R.; Ribeiro, D.A.; In vitro genotoxicity and cytotoxicity in murine fibroblasts exposed to EDTA, NaOCl, MTAD and citric acid. Braz Dent J 2012, 23(5), 527-533.

57. Kazak, M.; Donmez, N.; Bahadori, F.; Betul, V.; Kocyigit, A.A. Preliminary research study on the cytotoxicity of expired and non-expired composite resins: in vitro study. ODOVTOS-Int J Dental Sc 2020, 22-3: 123-134.

58. Spindola, D.G.; Hinsberger, A.; de Souza Antunes, V.M.; Michelin, L.F.G.; Bincoletto, C., Oliveira, C.R. In vitro cytotoxicity of chemical preservatives on human fibroblast cells. Braz J Pharm Sci 2018, 54(1), e00031. https://dx.doi.org/10.1590/s2175-97902018000100031

59. Jeong, H.; Hwang, J.; Lee, H.; Hammond, P.T.; Choi, J., Hong, J. In vitro blood cell viability profiling of polymers used in molecular assembly. Sci Rep 2017, 7, 9481-9494. https://doi.org/10.1038/s41598-017-10169-5 